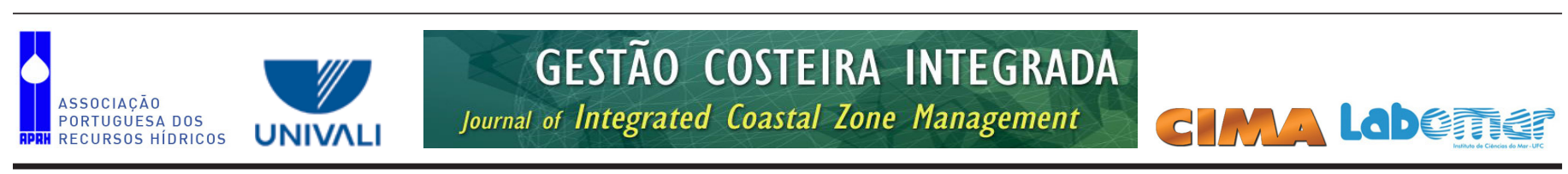

http://www.aprh.pt/rgci/pdf/rgci-452_Camacho.pdf | DOI:10.5894/rgci452

\title{
Geochemical characteristics of sediments along the margins of an atlantic-mediterranean estuary (the Guadiana, Southeast Portugal): spatial and seasonal variations*
}

\section{Características geoquímicas das margens dum estuário Atlanto-Mediterrânico (o Guadiana, Sudeste de Portugal): variação espacial e sazonal}

\author{
Sarita Camacho ${ }^{\circledR, 1}$, Delminda Moura ${ }^{1}$, Simon Connor ${ }^{1,2}$, Tomasz Boski ${ }^{1}$, Ana Gomes ${ }^{1}$
}

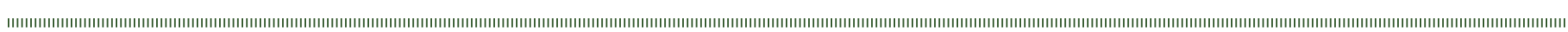

\section{ABSTRACT}

The present work describes spatial and seasonal variability in grain-size, $p H$ and elemental characteristics (TOC, TIC, TN and C/N) in superficial sediments, as well as salinity, temperature and oxygen in the water, within the intertidal range of the Guadiana Estuary, SW Iberian Peninsula, during the year 2010. The results indicate that environmental parameters in the estuary are strongly dependent on spatial patterns, which reflect seasonal oscillations in freshwater discharge. The sediment is generally poorly sorted, with a symmetrical to very finely skewed distribution, in accordance with the low-energy conditions typical of the deposition areas. During winter, heavy rains forced the continuous discharge of Europe's largest reservoir, the Alqueva dam, creating exceptional hydrodynamic conditions and causing coarser sediment deposition in the estuary. High marsh areas are controlled by flood tides, promoting vertical accretion of muddy sediments, especially silts. The lower areas of the saltmarsh and-mud flat areas are controlled by the ebb, with more efficient export of fines toward the platform and retention of sands, sometimes with significant amounts of bioclasts. In winter (average $Q=654 \mathrm{~m}^{3} \mathrm{~s}^{-1}$ ), salinity remained low throughout the estuary with the highest values $(<3)$ recorded up to $3 \mathrm{~km}$ inland from the river mouth, except in the most confined environments subject to greater evaporation. In summer (average $Q=52 \mathrm{~m}^{3} \mathrm{~s}^{-1}$ ), the estuarine waters are better mixed and significant saltwater intrusion extends approximately $8 \mathrm{~km}$ inland. The seasonal variation in surface water temperature was very high, with a difference of $c a 14^{\circ} \mathrm{C}$ in the maximum temperature recorded in winter and summer.

A clear relationship between elevation (in relation to mean sea level) and organic matter, $p H$ and particle size was observed. In the higher areas of the marsh, where the hydrodynamics is attenuated, differential deposition of fine sediments promotes organic matter entrapment and low $p H$. Sedimentary organic matter derives from a mixture of native aquatic and terrestrial sources. The mid-upper estuary areas and higher zones of the saltmarsh in the lower estuary incorporate a greater terrestrial component, whereas the low-middle marsh areas of the lower estuary experience a substantial contribution from indigenous aquatic sources.

The present data help to understand the present environmental condition of the Guadiana Estuary and contribute baseline data for future climatic and environmental management studies based on sediment-dependent proxies.

Keywords: Guadiana Estuary; saltmarsh; sediments; granulometry; organic matter; pH; physico-chemical proprieties.

\section{RESUMO}

O presente estudo descreve a variabilidade espacial e sazonal das propriedades físico-químicas da água (salinidade, temperatura e oxigénio) e dos sedimentos superficiais (granulometria, pH, COT, CIT, NT e C/N) da faixa intermareal do estuário do rio Guadiana, SW da Península Ibérica durante o ano 2010. Os resultados indicam que as condiçóes ambientais do estuário estáo fortemente dependentes

@ - Corresponding author: scamacho@ualg.pt

1 - CIMA, Faculdade de Ciências e Tecnologia, Universidade do Algarve, Campus de Gambelas, 8005-139 Faro, Portugal

2 - School of Geography and Environmental Science, Faculty of Arts, Monash University, Clayton 3800, Australia 
dos padrôes espaciais e das oscilaçóes sazonais na descarga de água doce. Os sedimentos apresentaram-se geralmente mal calibrados e com uma assimetria tendencialmente fina, de acordo com as condições de baixa energia típicas de áreas de deposição. As fortes chuvas sentidas durante o inverno forçaram a descarga contínua do maior reservatório artificial da Europa, o Alqueva, criando condiçôes hidrodinâmicas excecionais, promovendo o aumento de sedimentos grosseiros no estuário. A granulometria dos sedimentos ao longo da zona intertidal tende a aumentar das zonas mais elevadas às zonas mais baixas. As zonas de sapal alto são controladas pela enchente, promovendo a acreção vertical de sedimentos lodosos, sobretudo siltes. As zonas mais baixas do sapal e zonas de planície lodosa são controladas pela vazante, com exportação mais eficiente de finos para a plataforma e retenção de areias, por vezes com conteúdo significativo em bioclastos. No inverno (média $\mathrm{Q}=654 \mathrm{~m}^{3} \mathrm{~s}^{-1}$ ), a salinidade manteve-se baixa ao longo de todo o estuário, com os valores mais elevados $(<3$ ) registados até cerca de $3 \mathrm{~km}$ para montante a partir da foz do rio, exceto nos ambientes mais confinados, mais expostos à evaporação. No verão (média $\mathrm{Q}=52 \mathrm{~m}^{3} \mathrm{~s}^{-1}$ ), as águas estuarinas apresentaram-se melhor misturadas e a intrusão salina estendeu-se até cerca de $8 \mathrm{~km}$ para montante. A variação sazonal da temperatura das águas superficiais foi muito elevada, verificando-se uma diferença de $c a 14^{\circ} \mathrm{C}$ entre as temperaturas máximas registadas no Inverno e no Verão.

No estuário, observou-se uma clara relação entre a elevação (relativa ao nível médio do mar) e a quantidade de matéria orgânica, o tamanho do grão e o pH. Nas zonas mais elevadas do sapal, onde o hidrodinamismo é atenuado, a deposiçáo diferencial de sedimentos finos promove o aprisionamento de matéria orgânica e a diminuição do $\mathrm{pH}$.

A matéria orgânica sedimentar deriva de uma mistura de matéria orgânica aquática e terrestre de origem autóctone. As zonas do estuário médio-superior e as zonas mais elevadas do sapal do estuário inferior incorporam uma maior componente orgânica de origem terrestre, enquanto que as áreas de baixo-médio sapal do estuário inferior experienciam uma contribuição substancial proveniente de fontes aquáticas de origem alóctone.

A presente informação contribui para o melhor entendimento da atual condição ambiental do Estuário do Rio Guadiana e fornece dados de base para futuros estudos de gestão ambiental e evolução climática que assentem em indicadores ambientais sedimentares.

Palavras-chave: Estuário do Guadiana; sapal; sedimentos; granulometria; matéria orgânica; pH; propriedades físico-químicas.

\section{INTRODUCTION}

During the past century, the dynamic equilibrium of estuaries has been increasingly affected by anthropogenic intervention. The particular environmental characteristics of these coastal systems, as well as their high economic potential, made them attractive to human activities that tend to alter the fragile balance at the ocean/continent interface (Viles and Spencer, 1995; Wolanski, 2007; Vargas et al., 2008; Dias et al., 2009). There is growing concern around coastal zone development and management for sustainable use of estuarine resources (Savenije, 2005). Mediterranean estuaries, in particular, may be more vulnerable to impact due to the additional fragility that comes from their extreme characteristics, especially the long tidal flushing times, clear skies, high insolation, and low humidity that occur in summer (Hearn, 1998). The Guadiana system shares characteristics of both Atlantic and Mediterranean estuaries, experiencing a meso-tidal regime and frequent summer drought. The Guadiana has the fourth largest drainage basin of the Iberian Peninsula (see Dias et al., 2004) and its estuary represents, at the European level, an area of high ecological importance. The Lower Guadiana River is listed as a Wetland of International Importance (Ramsar, s.a.) and is included in the Natura 2000 Network. Its extensive marshlands were declared a Natural Reserve in 1975 due to their high biological and ecological value (ICNB, 2007). However, during the last few decades, several anthropogenic disturbances have changed the hydrodynamic and ecological balance of the estuary. Pollution sources in the Guadiana basin - mainly from increasing urbanization (sewage discharges), agriculture (fertilizers, pesticides and herbicides), cattle breeding, industries and the effects of intense mining in the past - have adversely affected water quality (INAG, 2001; Wolanski et al., 2006; Morais, 2008). The morphology of the estuary mouth has changed dramatically since the construction of two jetties, inhibiting longshore drift and reducing marine sediment influx (Dias et al., 2004). Dam construction in the watershed is probably the most significant environmental stressor affecting particulate and dissolved matter delivery to the Guadiana Estuary and to the sea. It is estimated that the Alqueva dam, which was commissioned in 2002, and dozens of smaller dams retain approximately $80 \%$ of the sediment in the catchment (Dias et al., 2001; Rocha et al., 2002). The retention of those sediments has implications for the sedimentary processes, such as coastal erosion and marine sedimentation in the low estuary and in the nutrient balance of the estuary (Morais, 2008).

Global climate changes occurring during recent decades, resulting from both human activity and the natural variability of climatic system, have led to an accelerated sea level rise (SLR) during the past century (Church and White, 2006; Domingues et al., 2008; Jevrejeva et al., 2008; Velicogna, 2009; Rignot et al., 2011; Gehrels and Woodworth, 2013; Bromwich et al., 2103). Its most striking effects are the gradual inundation of wetlands and coastal lowlands, erosion of beaches, more frequent and severe flooding, and higher salinity in rivers, bays, aquifers, and wetlands (Vargas et al., 2008; Sampath et al., 2011). Increasing anthropogenic influence in coastal zones and in the Guadiana Estuary in particular, combined with the threats posed by predicted sea-level rise, necessitates the acquisition of scientific information about the estuary's present condition and longterm monitoring of changes in biochemical and geochemical parameters (Dias et al., 2009).

Over the past decade, considerable scientific effort has been concentrated on the Guadiana Estuary to build up baseline knowledge about aquatic communities and water quality (Chícharo et al., 2006a, b; Cravo et al., 2006; Domingues et al., 2005; 2007; 2012; Faria et al., 2006; Morais et al., 2009a; Rocha et al., 2002). However, the 
Guadiana’s intertidal margins, which host thriving biological activity and exhibit a remarkable biodiversity (Gomes et al., 2013), have not yet been treated in detail. Baseline data that are essential for predicting future scenarios and performing paleoenvironmental reconstructions are absent. To fill this gap, the present work provides an analysis of the spatial and seasonal variability of grain-size, $\mathrm{pH}$ and bulk organic matter proxies in the superficial sediments of the Guadiana's intertidal zones and the physicochemical parameters of the interstitial waters. Based on the integration of these data, it is expected to identify the major forcing factors under contrasting seasonal and hydrodynamic conditions. This will improve understanding of the functioning of this highly seasonal, regulated estuarine system, providing useful tools in integrated coastal zone management in the southern Iberian Peninsula.

\section{STUDY AREA}

\subsection{Guadiana River Estuary}

The Guadiana Estuary is one of the most important mesotidal fluvio-marine systems of the south-western Iberian Peninsula (Morales, 1997; Morales et al., 2006). Its basin has Mediterranean climatic characteristics, with hot, dry summers, strong insolation and high evapotranspiration. The winters are relatively rigorous in the more elevated catchment zones (north, northeast) and become milder downstream (INAG, 2001). The river headland is located in Lagoas de Ruidera in Spain, at $1700 \mathrm{~m}$ altitude, and runs $810 \mathrm{~km}$ until reaching the Atlantic Ocean between the Portuguese town of Vila Real de Santo António and Spanish town of Ayamonte. The Portuguese stretch of the river is $260 \mathrm{~km}$, of which $110 \mathrm{~km}$ delimit the border with Spain (INAG, 2001) (Fig. 1). The Guadiana Estuary represents a rich wetland zone, where saltmarshes dominate and salt pans, lagoons, tidal creeks, intertidal flats, barrier islands and sandy spits and many other habitats of high ecological value are found (Boski et al., 2008). The wetland is noteworthy for its halophytic saltmarsh communities (Ramsar, s.a.), which carry out an essential role in the functioning and maintenance of healthy ecosystem status (Simonson, 2007). Before Alqueva Dam was commissioned, the hydrological regime of the Guadiana River was characterized by irregular discharges on both seasonal and inter-annual scales as a consequence of its dry Mediterranean climate and the poor permeability of its hydrological basin rocks. During periods of intense rainfall (deluges), the Guadiana flow could exceed $10000 \mathrm{~m}^{3} / \mathrm{s}$, contrasting with negligible flow during summer (MARETEC, s.a.). With artificial regulation, river flow is still dependent on climatic variability, but the effects of wet years are diminished (extreme flood episodes are controlled) and the effects of drought years are exacerbated. Data for rainfall and river discharges for the Guadiana River basin show a strong link with North Atlantic Oscillation (NAO) index patterns (Dias et al., 2004). The NAO is the dominant mode of winter climate variability in the North Atlantic region, ranging from central North America to Europe and even into northern Asia. A negative NAO index (dry conditions in the northern latitudes) usually results in more rainfall in the southern latitudes of Europe, and subsequent flooding in the river basin during winter months (Dias et al., 2004).

Physically, the estuary extends some $79 \mathrm{~km}$ inland, beginning $7 \mathrm{~km}$ upstream of the town of Mértola (Lopes et al., 2003). The estuary has a funnel shape, with an average width of $200 \mathrm{~m}$ at Mértola, progressively increasing to $600 \mathrm{~m}$ at the mouth (Lopes et al., 2003), where it cuts into Pliocene sands (Morales, 1995; Morales et al., 2006). The estuarine paleovalley is largely filled with sediments which accumulated during the last 14 Kyrs (Boski et al., 2008) and formed a delta that has been accreting since the Mid-Holocene stabilization of the sea-level (Morales et al., 2006).

According to recent data (IH, 2012), the mean channel depth varies from $7 \mathrm{~m}$ in the upper estuary to $6.8 \mathrm{~m}$ in the middle part and $4.5 \mathrm{~m}$ in the lower part (Fig. 2).

Maximum turbidity is observed, depending on tides and river inflow, between $20-38 \mathrm{~km}$ upstream of the mouth (Dias et al., 2001; 2004; Morais et al., 2009a).

The combined effect of tides and freshwater inputs control the vertical mixing and stratification at the Guadiana Estuary. Its highly variable flow regime, together with the constriction of the flow within the narrow estuarine channel, promotes a high range in mixing conditions (Garel et al., 2009). Well mixed (during spring tides) and partially stratified conditions (during neap tides) alternate during periods of low river flows; highly stratified conditions are observed during periods of high freshwater inflows (Oliveira, 2006; Garel et al., 2009; Garel and Ferreira, 2011).

\subsection{River and rainfall data}

Daily river inflow was measured at Ponte Quintos hydrometric station $(26 \mathrm{~L} / 01 \mathrm{G})$, downstream of the last dam on the river's main course. Monthly rainfall data are derived from Reguengos meteorological station $(23 \mathrm{~L} / 01 \mathrm{G})$. Both data sets were obtained from the Portuguese National Water Institute's public database (http://snirh.pt).

According to river inflow and rainfall data for 2010 (SNIRH, 1995-2014), the sampling year for the present study, major discharges coincide with periods of higher precipitation (Fig. 3). The 2010 winter was very wet, with strong discharge periods ( $Q$ average $654 \mathrm{~m}^{3} \mathrm{~s}^{-1}$ ), especially during March, when maximum discharge values of 2111.3 $\mathrm{m}^{3} \mathrm{~s}^{-1}$ were registered in Ponte Quintos. Indeed, the winter 2009/2010 was notable for the record negative NAO index in the 187-year record of Jones et al. (1997) (cited in Osborn, 2001) indicating a very unusual nature of atmospheric circulation over the Atlantic/European region. The winter 2009/2010 (December to March average) value of the NAO index $(-2.54)$ is considerably more negative than the previous four most negative index winters (1995/1996, 1962/1963, $1968 / 1969$ and 1916/1917) which all had NAO indices close to -1.7 (Osborn, 2011; 2014).

The NAO index for 2010's summer period (June to September) was also negative, although increasing to -1.7 (Osborn, 2014). That summer was typically dry, with low precipitation verified only for June and September (Fig. 3) and low, controlled, discharges (Q average $52 \mathrm{~m}^{3} \mathrm{~s}^{-1}$ ). 

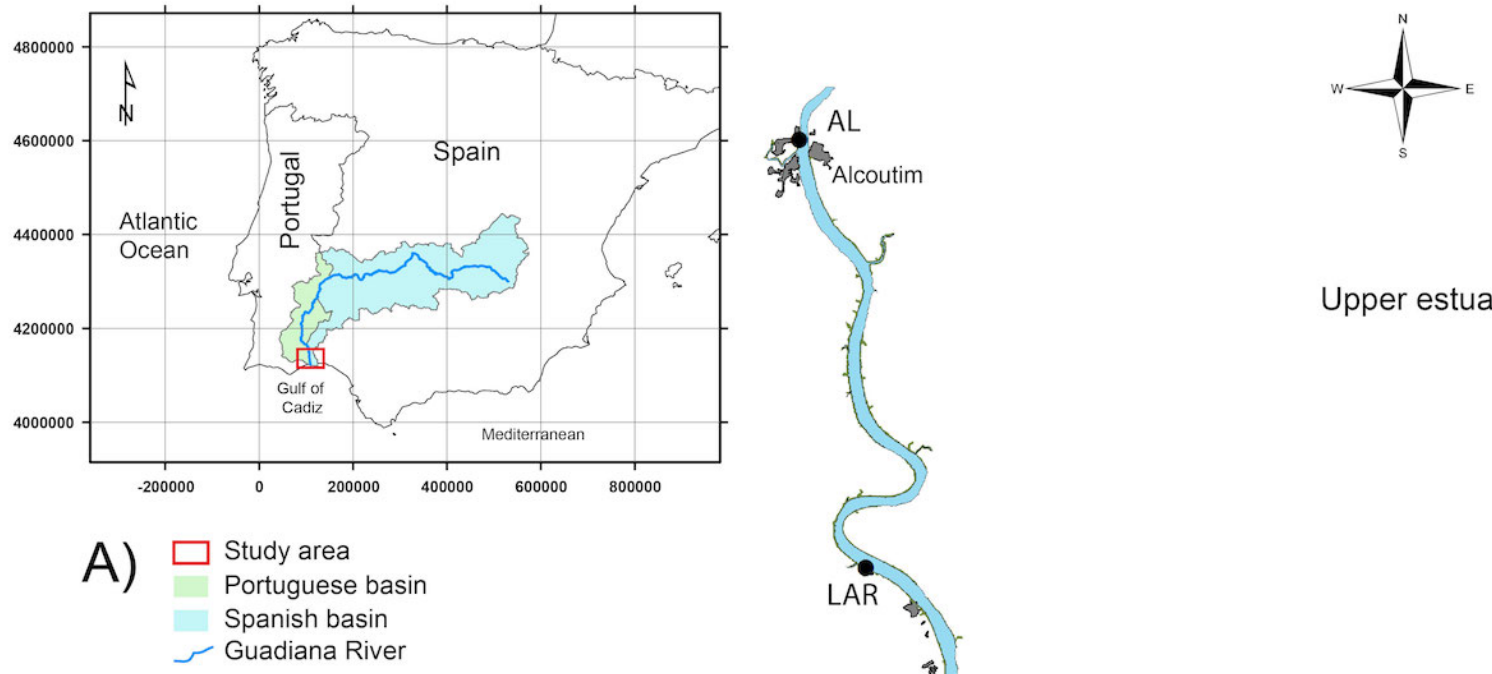

\section{Legend}

- Sampling transects

- Sampling points

Sea, river and channels

\section{Land use types}

\begin{tabular}{l}
\hline Urban infrastructures \\
Bealt and aquaculture pans \\
Beand \\
Sinewood \\
Salt marsh and river alluvial margins \\
Other land use type
\end{tabular}

\section{Sites}

AL - Alcoutim

LAR - Laranjeiras

FO - Foz de Odeleite

Aouro - Almada d'Ouro

FB - Foz do Beliche

PI - Ponte Internacional

LEZ - Lezíria

SCM - Sapal de Castro Marim

VRSA - Vila Real de Santo António

EE - Espanha ETAR

E - Espanha

LG - Lagoa
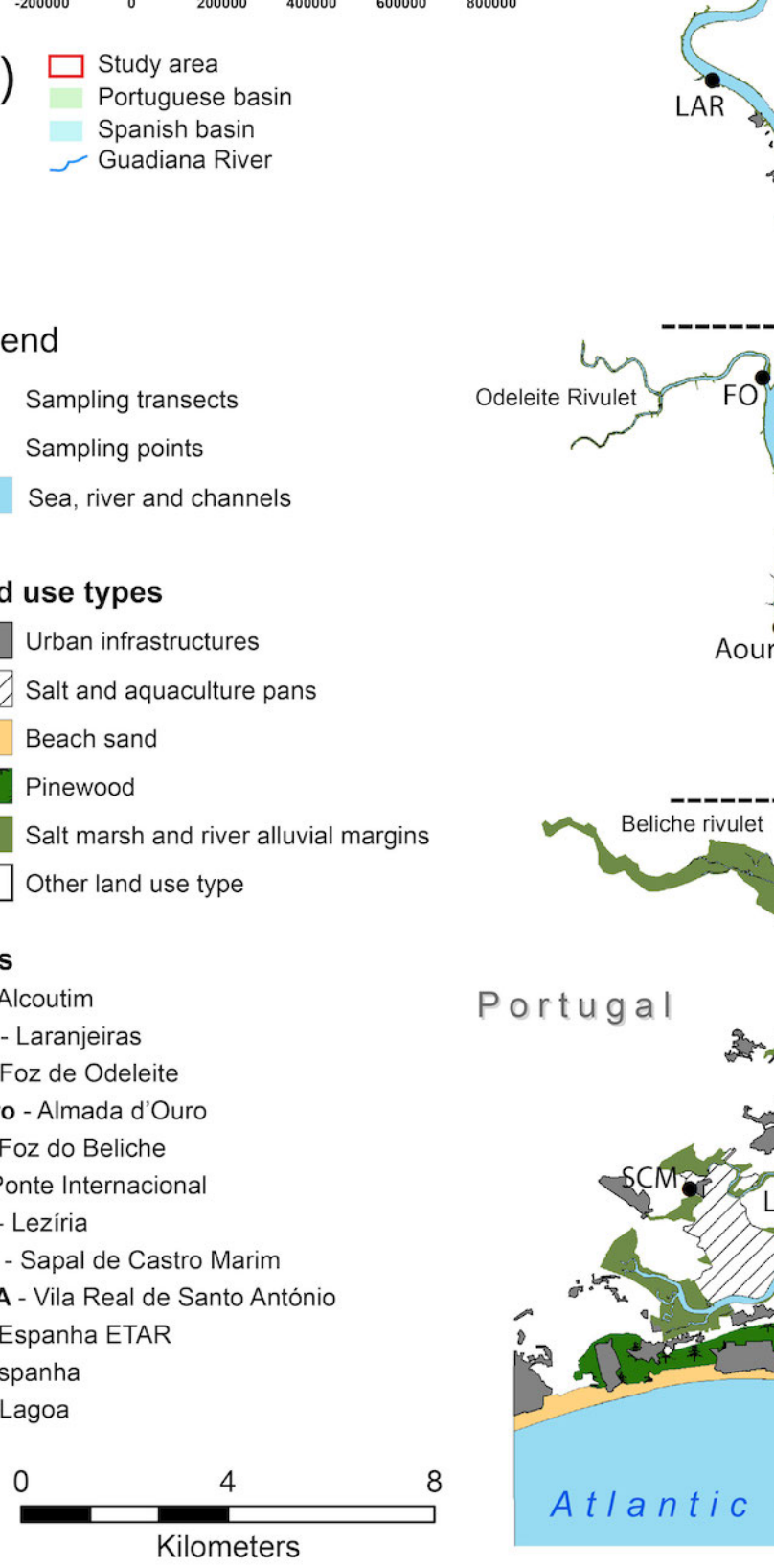

Upper estuary
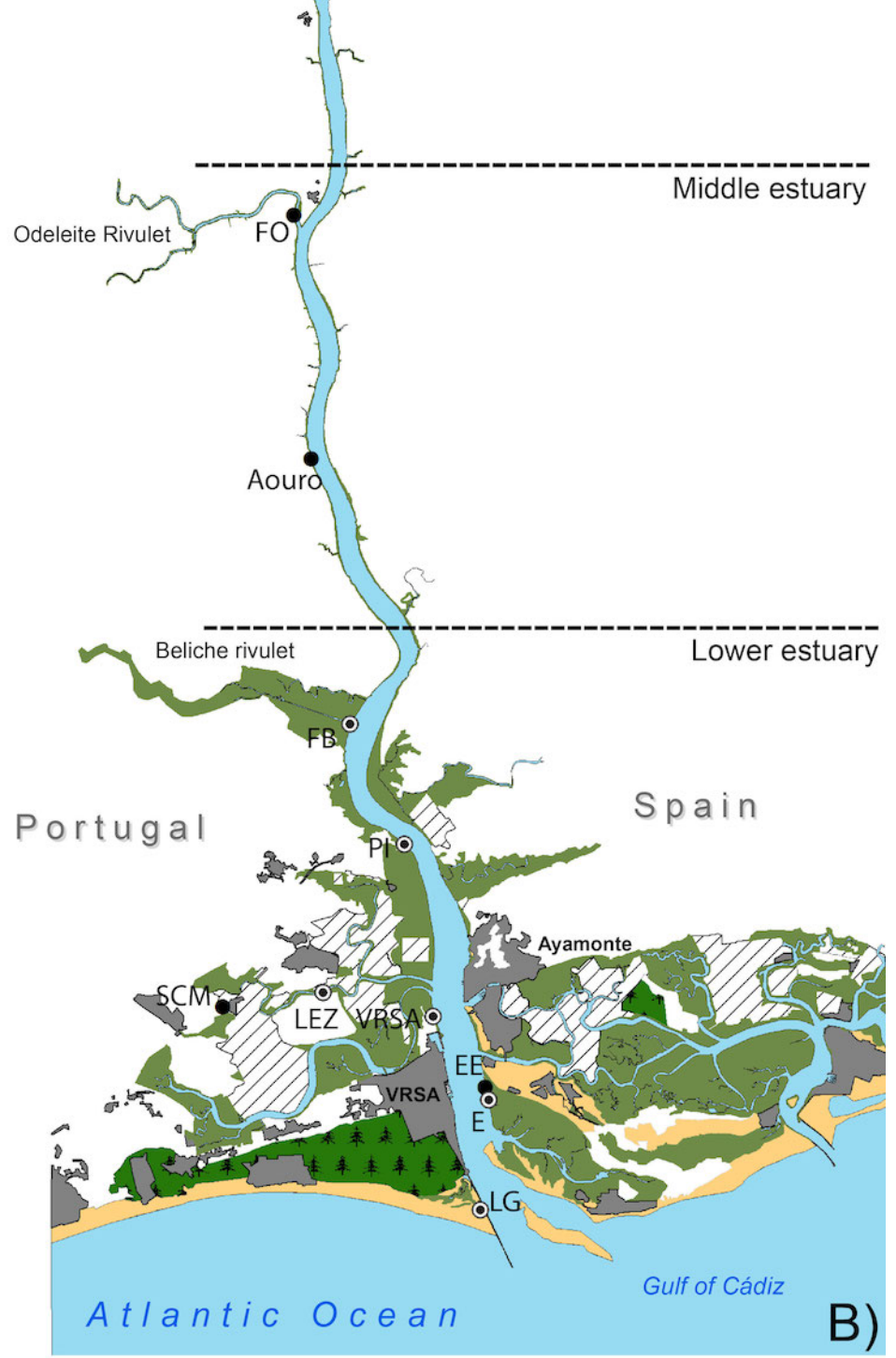

Figure 1. Localization of the study area; A) Geographical context of the Guadiana River basin in the Iberian Peninsula (Europe). Adapted from chguadiana.es (2012). Coordinate system: Datum ETRS89 UTM Zone 30N; B) Study area: Map of Guadiana River Estuary with site location.

Figura 1. Localização da área de estudo; A) Contexto geográfico da bacia do Rio Guadiana na Península Ibérica (Europa). Adaptado de chguadiana.es (2012). Sistema de coordenadas: Datum ETRS89 UTM Zona 30N; B) Área de estudo: mapa do Estuário do Rio Guadiana com a localização das estaçôes de amostragem. 
River bathymetry (m) relation to $M S L$
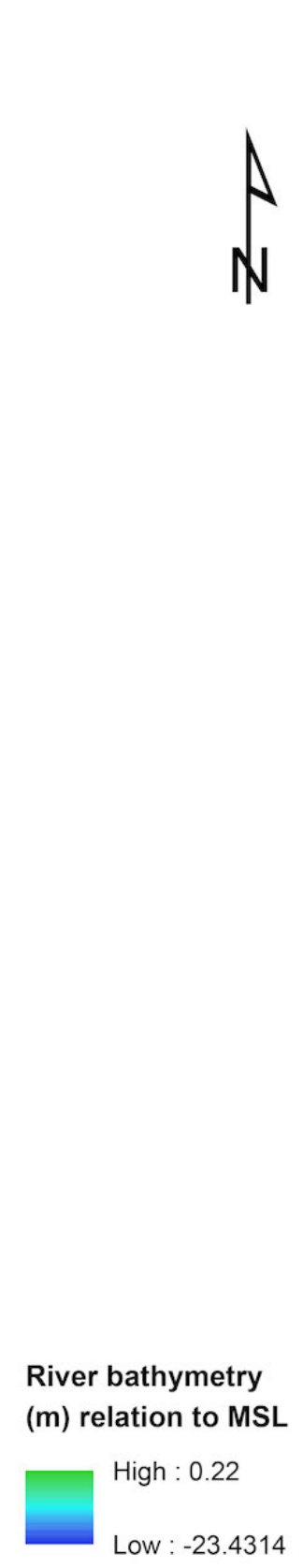

Portugal

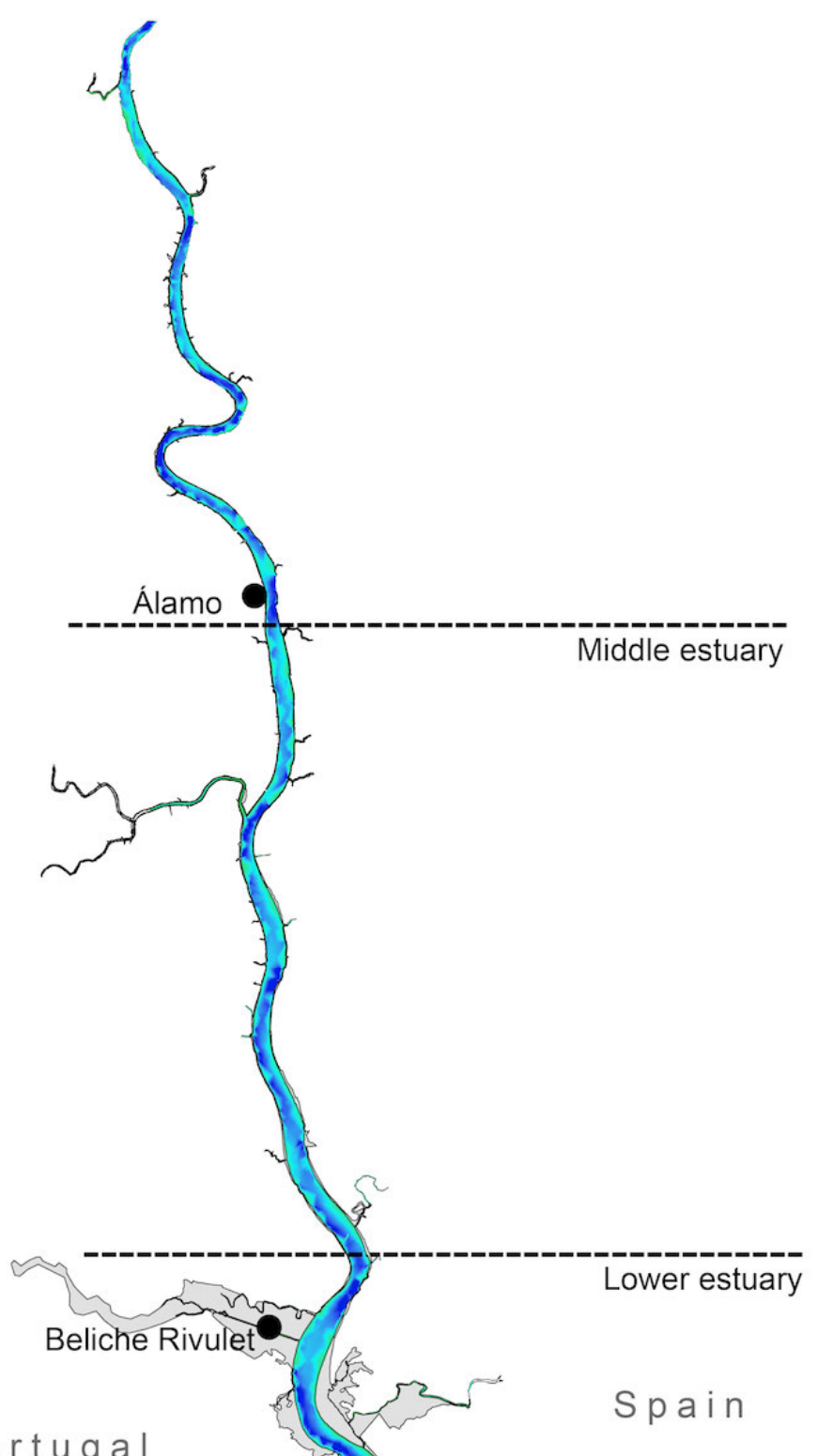

wetlands
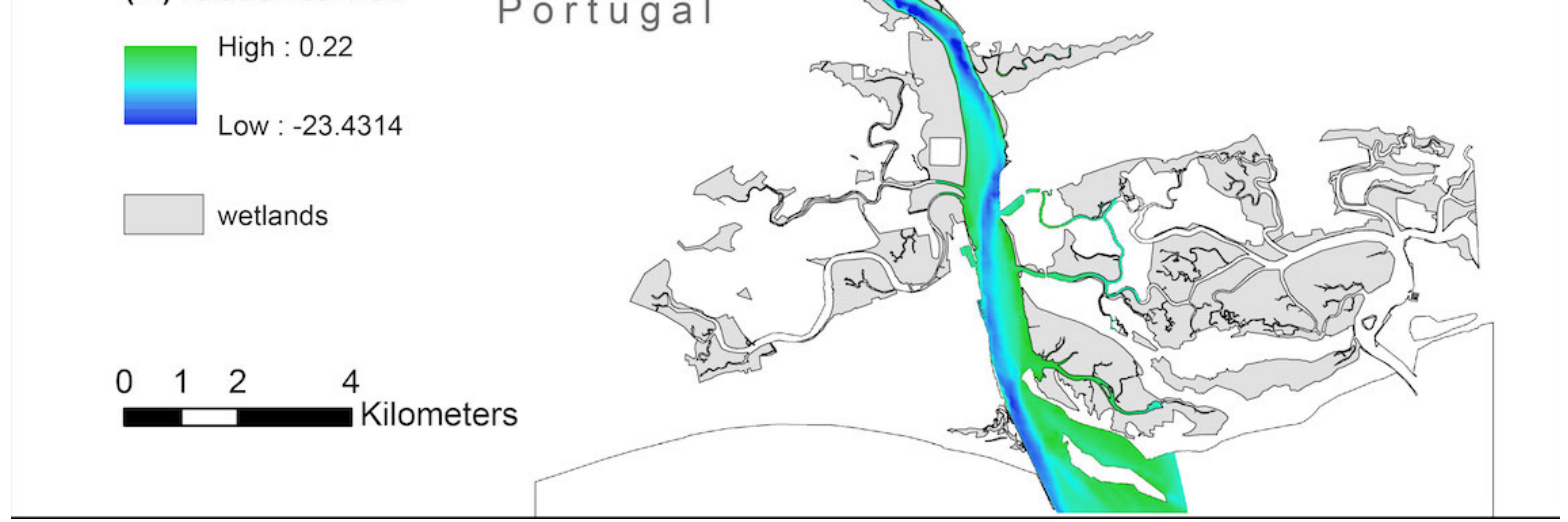

Figure 2. Guadiana Estuary - spatial division and bathymetry.

Figura 2. Estuário do Rio Guadiana-divisáo espacial e batimetria. 


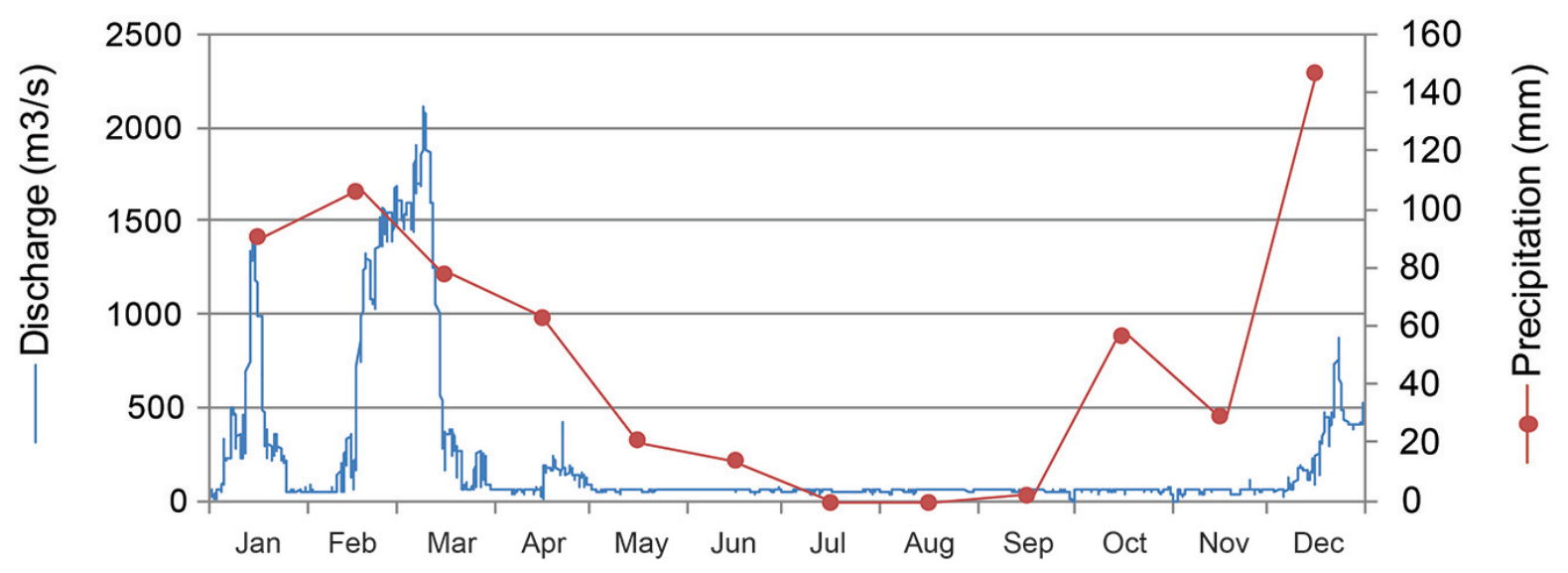

Figure 3. Daily discharge values during 2010 registered at Ponte Quintos hydrographic station (26L/01H) and monthly precipitation values during the same year at Reguengos meteorological station (23L/01G) (SNIRH, 19952014).

Figura 3. Valores de descarga diária durante o ano de 2010, registados na estação hidrográfica de Ponte de Quintos (26L/01H) e valores de precipitação mensais durante o mesmo ano, medidos na estaçáo meteorológica de Reguengos (23L/O1G) (SNIRH, 1995-2012).

\section{MATERIAL AND METHODS}

\subsection{Sampling strategy}

During 2010, two field campaigns were carried out, one in winter and another in summer, in the most contrasting environmental conditions. Sampling extended over $34 \mathrm{~km}$, from the river mouth upstream, to the locality of Alcoutim (Fig. 1), thus covering the entire estuary in chemical sense (significant saline intrusion) and an important part of the estuary in physical sense (tidal physical effects). Geographic coordinates for the twelve sampling locations appear in Table A1, Appendix A.

In the middle and upper estuary, one sample was collected at each site due to lack of saltmarsh zonation. In the lower estuary, where the environmental zonation is well-marked due to the stronger effect of the tidal range, several sediment samples were collected along transects aligned perpendicular to the river. The transects were placed according to the vertical zonation of halophytic vegetation from unvegetated mud-flats to the higher levels of the marshlands (e.g., Fig. 4). From the twelve different sites, six individual samples and six transects were collected, resulting in a total of 50 samples (24 in winter and 26 in summer). Sites AL and PI1 were not sampled in winter due to adverse weather. The sampling points were georeferenced using a differential Global Positioning System (d-GPS), a Trimble 5800 mobile unit, and a Nikon DTM 310 Total Station. Elevation values were measured in relation to mean sea level (MSL) (Fig. 4). The elevation gradient was divided in three levels: upper marsh (samples collected at 1-2 $\mathrm{m}$ above MSL), middle marsh (0-1 $\mathrm{m}$ above MSL), and lower marsh (-1-0 $\mathrm{m}$ in relation to MSL). The longitudinal position with respect to the estuarine channel was divided into lower, middle and upper estuary (Fig. 1) (Boski et al., 2006).

Sample collection and physicochemical measurements were always performed during ebb tide. At each sampling point, ca. $300 \mathrm{~g}$ of the uppermost $2-3 \mathrm{~cm}$ of sediment were collected for bulk organic matter and sedimentological analyses. Salinity (Sal), temperature $(\mathrm{T})$ and dissolved oxygen (DO) in the sediment interstitial water were measured in situ using an Ysi 556 MPS handheld multiparameter probe. Sediment $\mathrm{pH}$ (pHsed) was measured at the sediment surface with a waterproof portable $\mathrm{pH}$-meter, model spear, from EUTECH.

\subsection{Granulometry}

Prior to granulometric analysis, organic matter content was removed with $\mathrm{H}_{2} \mathrm{O}_{2}(33 \%)$. Size distribution of the fine grained samples was measured with a Malvern Mastersizer X laser particle-size analyzer. For mixed samples (containing both fine and coarse sediments) ca. $100 \mathrm{~g}$ were weighed, washed and separated using a $63 \mu \mathrm{m}$ sieve, resulting in coarser and finer fractions. The coarser fraction was dry sieved through a set of stainless steel sieves (half-phi intervals) in a sieve shaker (Retsch AS 200 base, for 10 minutes at $50 \%$ amplitude). Each dimensional component of the finer fraction was determined based on its sedimentation velocity, evaluated by aliquot pipette sampling, according to Stokes law (Lewis and McConchie, 1994a, b).

Statistical analyses of grain size were performed in GRADISTAT (Blott and Pye, 2001). The sediments were divided into gravel, sand and mud (i.e. silt and clay) (Folk, 1954). Granulometric mean, sorting, skewness and kurtosis, were also calculated for bulk sediment through the Folk and Ward (1957) method, based in a Log-normal distribution (geometrically) and expressed in metric units.

\subsection{Elemental analysis}

Total organic carbon (TOC), total inorganic carbon (TIC) and total nitrogen (TN) from the bulk sediment were analysed using gas chromatography. Prior to analysis samples 

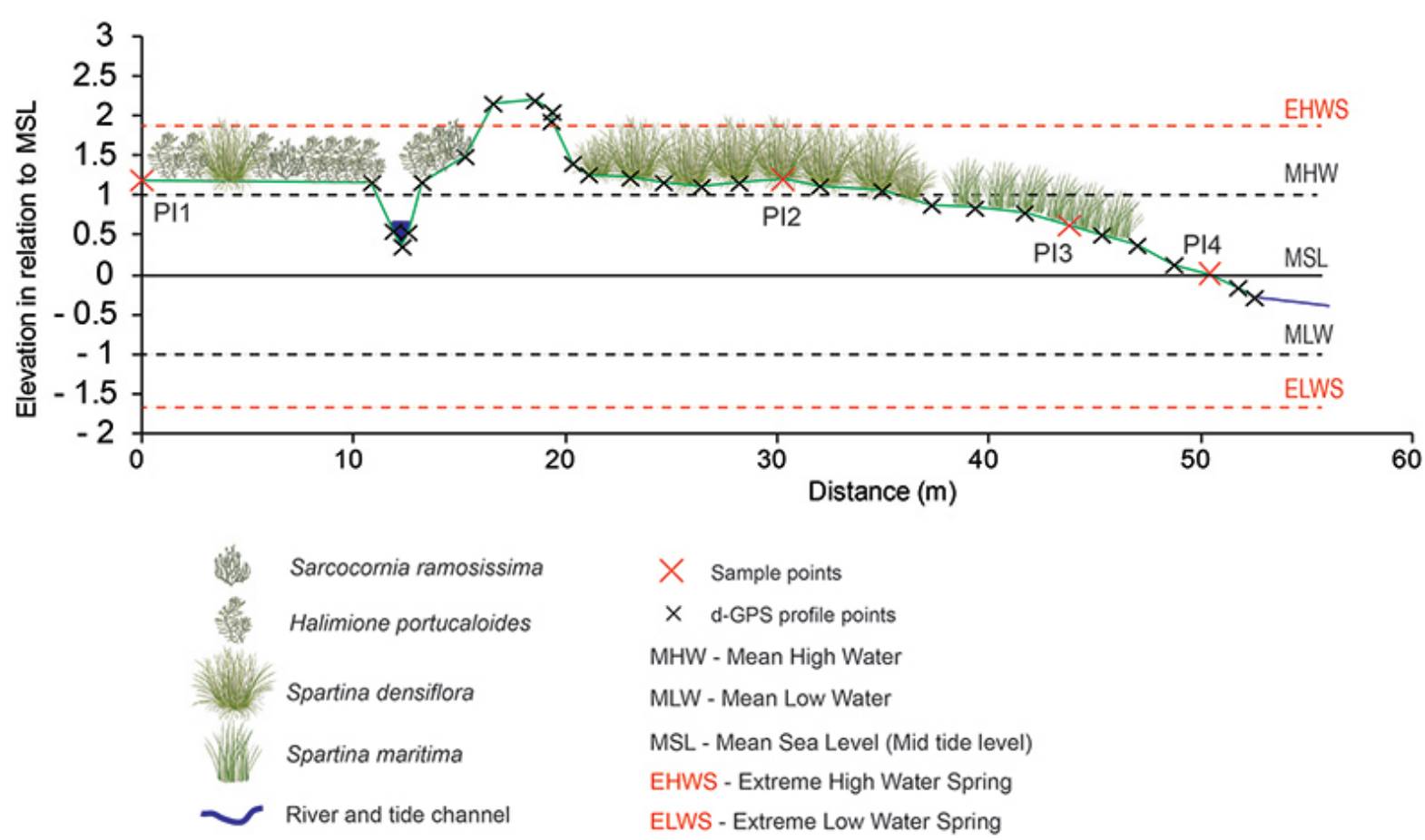

Figure 4. Halophytic and topographic characterization of PI profile, one of the seven surveyed profiles.

Figura 4. Caracterização da topografia e da flora halófita do perfil PI, um dos sete perfis estudados.

were lyophilized, then finely ground and homogenized in an agate micromill. Two aliquots of about $20 \mathrm{mg}$ were packed into tin and silver cups. The aliquots packed in silver cups were decarbonated using $25 \% \mathrm{HCl}$, prior to analysis in an EA 1108 Carlo Erba C/H/N/S Elemental Analyzer (Detection Limit of $10 \mathrm{ppm}$ ). The tin cup aliquots were directly analyzed without any pre-treatment. TN and TOC content were obtained from direct instrumental reading of a decarbonated sample and TIC content was calculated from the difference between the total carbon (TC) reading of an untreated sample and TOC. In the present work, C/N ratios are used as proxy of organic matter $(\mathrm{OM})$ following Meyers (1994). According to this author, $\mathrm{C} / \mathrm{N}$ may be used to distinguish between $\mathrm{OM}$ provenances in estuaries, since autochthonous marine organisms rich in proteins have much lower $\mathrm{C} / \mathrm{N}$ values than terrestrial plants. The $\mathrm{C} / \mathrm{N}$ ratio ranges followed are those presented by Bordovskiy (1965): 5.7 for actively growing marine phytoplankton; 6-9 are typically reported for autochthonous marine-derived $\mathrm{OM}$; whereas values greater than 12 are usually found in terrestrially derived OM (vascular plant material).

\subsection{Data analysis}

The sediment type (mud, sand and gravel) was represented graphically using ArcView software, according to elevation relative to mean sea level (tidal exposure) and latitudinal (distance to sea) gradients. The parameters were cross-correlated to highlight their main relationships using Pearson's or Spearman's coefficients, depending on the normality of the data, through STATISTICA, version 7.

\section{RESULTS}

\subsection{Granulometry}

A general, statistically significant (Table 1), trend of increasing grain-size from higher to lower saltmarsh was observed at each sampling location (Fig. 5).

With the exception of sample VRSA1, which comes from a disturbed area of sandy sediment, the remaining upper marsh samples are characterized by more than $90 \%$ mud content, of which $63-80 \%$ are silt fractions (Tables B.1 and B.2, Appendix B). The sediments were classified as fine to medium silt and were poorly sorted, symmetrical and trendily mesokurtic (Table 2).

At the other extreme, the lower saltmarsh zones had the coarsest sediments, with $51-87 \%$ sand content (Tables B.1 and B.2, Appendix B). Bioclasts contribute to the gravel fraction, representing up to $7 \%$ of the total sediment in samples from the left (Spanish) side of the estuary (stations $\mathrm{EE}$ and E2, Fig. 5). Sediments were classified as very coarse silt to fine sand and were very poorly sorted. The sediment distribution was very finely skewed and very leptokurtic (Table 2).

Seaward sediment coarsening was observed in the $0-1 \mathrm{~m}$ elevation interval (Fig. 5 and Tables B.1 and B.2, Appendix B). Although statistically insignificant, a positive relationship was found between latitude (distance to sea) and mud and a negative relationship between latitude and sand and gravel (Table 1). 
Table 1. Spearman's Rank Correlation $(R)$ or Pearson Correlation Coefficient $(\boldsymbol{r})$ between all spatial and physico-chemical variables. According to the normality of the variable, $(R)$ or $(r)$ is indicated for each pairwise, and are significant for $p<0.01(* *)$ and for $p<0.05\left(^{*}\right)$.

Tabela 1. Coeficientes de correlação, Spearman's Rank (R) ou Pearson ( $r$, entre todas as variáveis espaciais e físico-químicas. De acordo com a normalidade das variáveis, $(R)$ ou $(r)$ é indicado para cada conjunto de variáveis e é considerado significativo para $p<0.01$ (**) e para $p<0.05\left(^{*}\right)$.

\section{Winter}

\begin{tabular}{|c|c|c|c|c|c|c|c|c|c|c|c|}
\hline & TOC & TIC & $\mathrm{TN}$ & $\mathrm{C} / \mathrm{N}$ & Sal & $\mathrm{DO}$ & $\mathrm{T}$ & $\mathrm{pH}_{\text {sed }}$ & mud & sand & gravel \\
\hline Elev & $0.55^{* *}$ & -0.01 & $0.47^{*}$ & $0.43^{*}$ & -0.32 & 0.50 & $-0.56^{*}$ & -0.21 & $0.62^{* *}$ & $-0.60^{* *}$ & -0.15 \\
\hline Lat & 0.10 & $-0.52^{* *}$ & -0.01 & $0.71^{* *}$ & $-0.74^{* *}$ & 0.33 & -0.48 & -0.21 & 0.37 & -0.36 & -0.39 \\
\hline TOC & - & 0.32 & $0.75^{* *}$ & 0.39 & -0.09 & 0.12 & $-0.72^{* *}$ & $-0.52^{* *}$ & $0.78^{* *}$ & & \\
\hline TIC & 0.32 & - & 0.33 & -0.33 & $0.58^{*}$ & -0.52 & 0.11 & 0.03 & 0.04 & & \\
\hline $\mathrm{TN}$ & $0.75^{* *}$ & 0.33 & - & 0.21 & 0.05 & -0.04 & $-0.76^{* *}$ & $-0.51^{*}$ & $0.75^{* *}$ & & \\
\hline $\mathrm{C} / \mathrm{N}$ & 0.39 & -0.33 & 0.21 & - & -0.52 & 0.48 & -0.24 & -0.27 & $0.50^{*}$ & & \\
\hline Sal & -0.09 & $0.58^{*}$ & 0.05 & -0.52 & - & -0.17 & 0.15 & 0.22 & -0.19 & & \\
\hline $\mathrm{DO}$ & 0.12 & -0.52 & -0.04 & 0.48 & -0.17 & - & -0.33 & -0.14 & 0.29 & & \\
\hline $\mathrm{T}$ & $-0.72^{* *}$ & 0.11 & $-0.76^{* *}$ & -0.24 & 0.15 & -0.33 & - & $0.59^{*}$ & $-0.72^{* *}$ & & \\
\hline $\mathrm{pH}_{\text {sed }}$ & $-0.52^{* *}$ & 0.03 & $-0.51^{*}$ & -0.27 & 0.22 & -0.14 & $0.59^{*}$ & - & $-0.53^{* *}$ & & \\
\hline
\end{tabular}

\section{Summer}

\begin{tabular}{c|c|c|c|c|c|c|c|c|c|c|c}
\hline & TOC & TIC & TN & C/N & Sal & DO & T & $\mathrm{pH}_{\text {sed }}$ & mud & sand & gravel \\
\hline Elev & 0.26 & 0.11 & 0.23 & -0.04 & 0.03 & $-\mathbf{0 . 3 4}$ & -0.22 & $\mathbf{0 . 1 8}$ & $0.65^{* *}$ & $-0.64^{* *}$ & -0.15 \\
\hline Lat & 0.06 & $-0.44^{*}$ & 0.04 & 0.19 & $-0.85^{* *}$ & 0.50 & -0.38 & -0.23 & 0.19 & -0.19 & $-0.4^{*}$ \\
\hline TOC & - & 0.23 & $0.98^{* *}$ & -0.19 & 0.02 & -0.26 & $-0.56^{*}$ & $-0.40^{*}$ & $0.60^{* *}$ & \\
\hline TIC & 0.23 & - & 0.21 & 0.08 & 0.30 & -0.33 & -0.05 & 0.37 & 0.02 & \\
\hline TN & $0.98^{* *}$ & 0.21 & - & -0.35 & 0.03 & -0.29 & $-0.55^{*}$ & $-0.43^{*}$ & $0.57^{* *}$ & & \\
\hline $\mathrm{C} / \mathrm{N}$ & -0.19 & 0.08 & -0.35 & - & -0.34 & 0.43 & 0.09 & $0.41^{*}$ & -0.24 & & \\
\hline Sal & 0.02 & 0.30 & 0.03 & -0.34 & - & $-0.70^{* *}$ & 0.23 & 0.19 & -0.21 & & \\
\hline $\mathrm{DO}$ & -0.26 & -0.33 & -0.29 & 0.43 & $-0.70^{* *}$ & - & 0.02 & $-\mathbf{0 . 1 0}$ & -0.08 & & \\
\hline $\mathrm{T}$ & $-0.56^{*}$ & -0.05 & $-0.55^{*}$ & 0.09 & 0.23 & 0.02 & - & -0.01 & -0.53 & & \\
\hline $\mathrm{pH}$ & $-0.40^{*}$ & 0.37 & $-0.43^{*}$ & $0.41^{*}$ & 0.19 & $-\mathbf{0 . 1 0}$ & -0.01 & - & $-0.56^{* *}$ & & \\
\hline
\end{tabular}




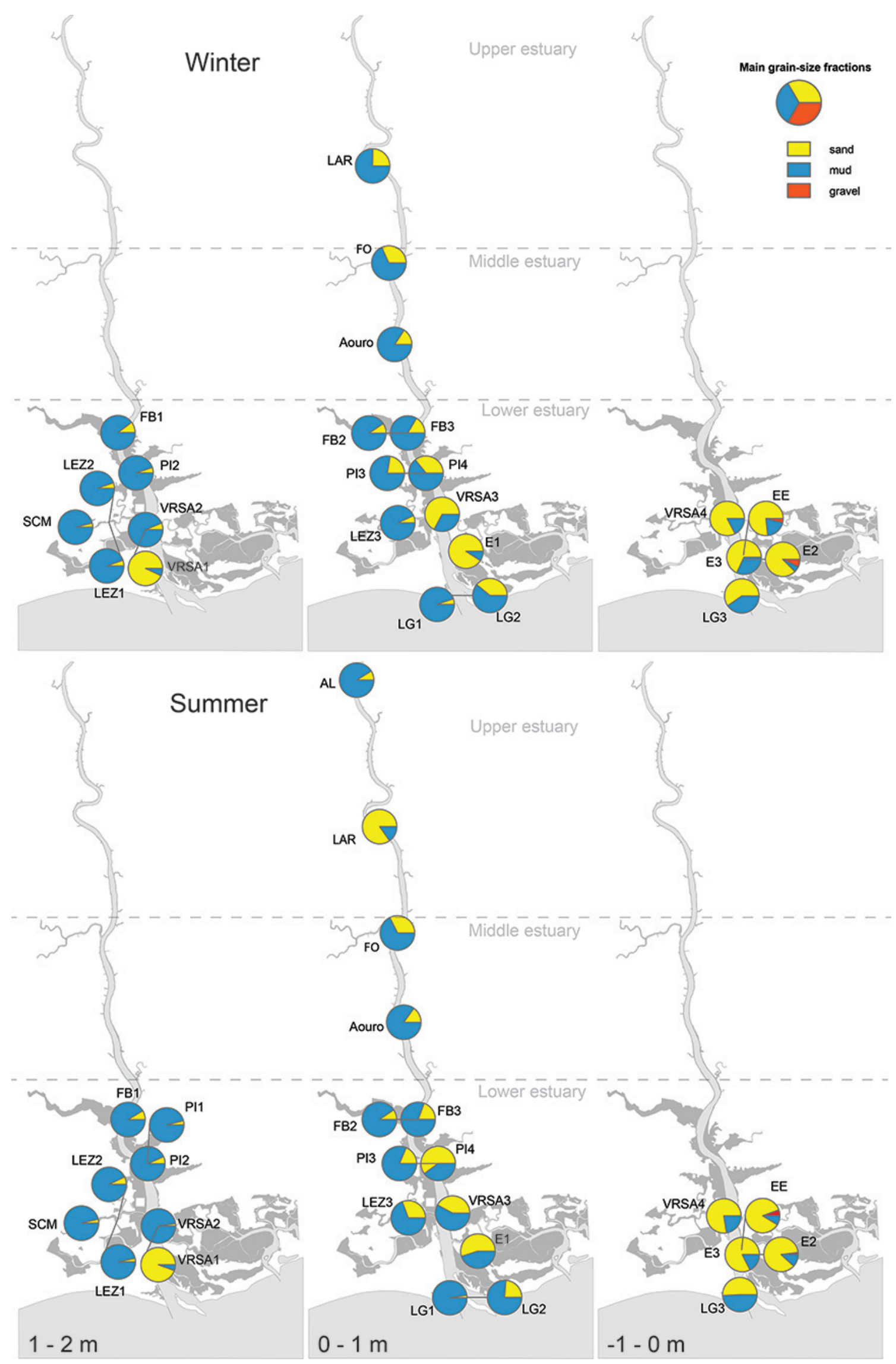

Figure 5. Diagrams showing the variation of mud, sand and gravel content along a north/south and elevation (relative to mean sea level) gradients of the Guadiana Estuary, during winter and summer.

Figura 5. Diagramas de variação do conteúdo em finos, areias e cascalho ao longo dos gradientes Norte/Sul e de elevação (em relação ao nivel médio relativo do mar) do Estuário do Guadiana, durante o Inverno e Verão. 
Table 2. Synthesis of the main sedimentological parameters along the Guadiana Estuary's margins. Elevation (Elev) is relative to mean sea level (see text, section 3.1).

Tabela 2. Síntese dos principais parâmetros sedimentológicos das margens do Estuário do Rio Guadiana. Elevação (Elev) é medida em relação ao nivel médio do mar (ver texto, seç̧âo 3.1).

\begin{tabular}{|c|c|c|c|c|c|c|}
\hline Season & \multicolumn{3}{|c|}{ Winter } & \multicolumn{3}{|c|}{ Summer } \\
\hline Elev MSL (m) & $1-2$ & 0 - 1 & $-1-0$ & $1-2$ & $0-1$ & $-1-0$ \\
\hline $\begin{array}{c}\text { Granulometric } \\
\text { mean }(\mu \mathrm{m})\end{array}$ & $\begin{array}{l}\text { fine silt to } \\
\text { medium sand }\end{array}$ & $\begin{array}{l}\text { fine silt to } \\
\text { medium sand }\end{array}$ & $\begin{array}{l}\text { very fine sand } \\
\text { to fine sand }\end{array}$ & $\begin{array}{c}\text { fine silt to fine } \\
\text { sand }\end{array}$ & $\begin{array}{c}\text { fine silt to fine } \\
\text { sand }\end{array}$ & $\begin{array}{l}\text { very coarse silt } \\
\text { to fine sand }\end{array}$ \\
\hline $\max$ & 278.16 & 287.97 & 219.97 & 201.99 & 141.83 & 248.50 \\
\hline $\min$ & 6.63 & 5.68 & 66.66 & 6.44 & 5.81 & 41.50 \\
\hline mean & 46.23 & 42.30 & 125.41 & 31.68 & 29.17 & 138.65 \\
\hline SD & 102.28 & 79.74 & 62.07 & 68.83 & 36.25 & 78.17 \\
\hline Sorting & poorly sorted & $\begin{array}{l}\text { very poorly } \\
\text { sorted }\end{array}$ & $\begin{array}{l}\text { very poorly } \\
\text { sorted }\end{array}$ & poorly sorted & $\begin{array}{l}\text { very poorly } \\
\text { sorted }\end{array}$ & $\begin{array}{l}\text { very poorly } \\
\text { sorted }\end{array}$ \\
\hline $\max$ & 4.32 & 9.32 & 8.93 & 4.27 & 7.27 & 6.82 \\
\hline $\min$ & 1.90 & 1.98 & 2.31 & 1.70 & 2.54 & 2.58 \\
\hline mean & 3.67 & 5.17 & 4.56 & 3.59 & 4.94 & 4.10 \\
\hline SD & 0.81 & 1.72 & 2.57 & 0.82 & 1.21 & 1.67 \\
\hline Skewness & symmetrical & $\begin{array}{l}\text { very fine skewed } \\
\text { to coarse } \\
\text { skewed }\end{array}$ & very fine skewed & symmetrical & fine skewed & very fine skewed \\
\hline $\max$ & -0.01 & 0.19 & 0.16 & -0.03 & 0.01 & -0.01 \\
\hline $\min$ & -0.11 & -0.62 & -0.64 & -0.14 & -0.61 & -0.61 \\
\hline mean & -0.06 & -0.08 & -0.35 & -0.09 & -0.21 & -0.43 \\
\hline SD & 0.03 & 0.21 & 0.35 & 0.04 & 0.22 & 0.24 \\
\hline Kurtosis & leptokurtic & mesokurtic & very leptokurtic & mesokurtic & mesokurtic & very leptokurtic \\
\hline $\max$ & 1.61 & 1.87 & 2.88 & 1.53 & 2.42 & 3.23 \\
\hline $\min$ & 1 & 0.68 & 0.74 & 0.96 & 0.75 & 0.69 \\
\hline mean & 1.12 & 1.02 & 1.87 & 1.07 & 1.04 & 1.80 \\
\hline SD & 0.22 & 0.33 & 0.85 & 0.19 & 0.43 & 0.94 \\
\hline
\end{tabular}

\subsection{Elemental parameters}

Sediment TOC values were highly variable $(0.2-9 \%)$ with no significant differences between winter and summer (Table 3). Mean TOC content decreases from the upper (3.6\%) to the lower marshes (1.4\%) (Tables 1 and 3). A relatively strong positive correlation between TOC and mud content was found in both seasons (Table 2). TN content varied between 0.02 to $1.1 \%$ (Table 3 ) and was strongly positively correlated with TOC in both seasons $(\mathrm{R}>0.96)$. TOC and TN tend to increase upstream (Table 3), although no significant correlation was observed (Table 1).

$\mathrm{C} / \mathrm{N}$ ratios are quite homogeneous along the estuary, ranging from 6 to 12 in the majority of samples (Table 3). Only a few samples had $\mathrm{C} / \mathrm{N}$ values $>12$, including FB1 in winter with 15.3. The lowest $\mathrm{C} / \mathrm{N}$ occurred at the $\mathrm{E} 2$ site in winter, but may be unreliable as its TOC value is lower than $0.3 \%$, the minimum necessary to reliably calculate $\mathrm{C} / \mathrm{N}$ (Meyers, 1997).

There was a decrease in $\mathrm{C} / \mathrm{N}$ from the upper to lower marshes in winter (Tables 1, 3). In summer this trend was not evident. $\mathrm{C} / \mathrm{N}$ had a positive, relatively strong correlation with latitude in winter $(\mathrm{R}=0.71)$, with the highest values in the northernmost samples, but this trend was not evident in summer. 
Table 3. Elemental and physico-chemical parameters of the sediment samples collected in winter and summer.

Tabela 3. Parâmetros elementais e físico-químicos das amostras de sedimento colbidas no Inverno e no Veráo.

\begin{tabular}{|c|c|c|c|c|c|c|c|c|c|c|c|c|c|c|c|c|c|}
\hline \multirow[b]{2}{*}{ Sample } & \multirow[b]{2}{*}{$\begin{array}{c}\text { Elev (MSL) } \\
\mathrm{m}\end{array}$} & \multicolumn{8}{|c|}{ winter } & \multicolumn{8}{|c|}{ summer } \\
\hline & & TOC & TIC & $\mathrm{TN}$ & $\mathrm{C} / \mathrm{N}$ & pHsed & Sal & $\mathrm{DO} \%$ & $\mathrm{~T}^{\mathrm{O}} \mathrm{C}$ & TOC & TIC & $\mathrm{TN}$ & $\mathrm{C} / \mathrm{N}$ & pHsed & Sal & $\mathrm{DO} \%$ & $\mathrm{~T}^{\circ} \mathrm{C}$ \\
\hline $\mathrm{AL}$ & 0.209 & & & & & & & & & 2.10 & 0.01 & 0.20 & 10.70 & 6.63 & 0.18 & 92.1 & 24.78 \\
\hline LAR & 0.311 & 1.98 & 0.21 & 0.17 & 11.55 & 7.19 & 0.25 & 104.5 & 12.62 & 0.57 & 0.04 & 0.06 & 10.02 & 7.30 & 0.18 & 85.3 & 25.66 \\
\hline FO & 0.334 & 1.42 & 0.08 & 0.16 & 8.65 & 7.39 & 0.13 & 89.1 & 14.31 & 8.95 & 0.64 & 0.69 & 12.99 & 6.77 & 0.22 & 78.8 & 26.46 \\
\hline Aouro & 0.532 & 2.00 & 0.06 & 0.16 & 12.58 & 7.38 & 0.23 & 106.6 & 13.11 & 1.16 & 0.19 & 0.13 & 9.17 & 7.69 & 0.43 & 73.4 & 26.79 \\
\hline FB1 & 1.432 & 6.25 & 0.28 & 0.41 & 15.31 & 6.96 & & & & 2.36 & 0.42 & 0.30 & 7.85 & 6.58 & & & \\
\hline FB2 & 0.752 & 2.32 & 0.30 & 0.22 & 10.47 & 6.95 & & & & 2.21 & 0.09 & 0.27 & 8.31 & 6.42 & & & \\
\hline FB3 & 0.471 & 3.12 & 0.21 & 0.27 & 11.38 & 6.84 & 0.24 & 85.3 & 12.87 & 3.24 & 0.22 & 0.30 & 10.81 & 6.73 & 2.81 & 76.4 & 26.35 \\
\hline PI1 & 1.188 & & & & & & & & & 4.16 & 0.00 & 0.57 & 7.40 & 6.38 & & & \\
\hline PI2 & 1.198 & 3.09 & 0.15 & 0.36 & 8.67 & 7.28 & & & & 3.47 & 0.09 & 0.37 & 9.47 & 6.00 & & & \\
\hline PI3 & 0.614 & 2.10 & 0.18 & 0.27 & 7.87 & 7.73 & & & & 2.35 & 0.29 & 0.23 & 10.03 & 6.77 & & & \\
\hline PI4 & 0.011 & 1.83 & 0.01 & 0.21 & 8.93 & 7.37 & 0.24 & 111.3 & 12.46 & 1.58 & 0.03 & 0.18 & 8.91 & 6.48 & 9.33 & 59.9 & 28.75 \\
\hline LEZ1 & 1.317 & 7.16 & 0.61 & 0.74 & 9.63 & 7.69 & & & & 5.94 & 0.51 & 0.58 & 10.26 & 6.57 & & & \\
\hline LEZ2 & 1.062 & 2.17 & 0.32 & 0.26 & 8.28 & 7.34 & & & & 2.63 & 0.29 & 0.29 & 9.04 & 7.02 & & & \\
\hline LEZ3 & 0.202 & 1.65 & 0.03 & 0.23 & 7.15 & 6.22 & 1.21 & 98.1 & 12.36 & 1.90 & 0.20 & 0.22 & 8.63 & 6.43 & 24.13 & 57.2 & 26.97 \\
\hline $\mathrm{SCM}$ & 1.96 & 3.40 & 0.48 & 0.31 & 11.06 & 7.01 & 14.30 & 115.0 & 12.43 & 5.12 & 0.38 & 0.44 & 11.60 & 6.98 & 26.10 & 35.2 & 20.18 \\
\hline VRSA1 & 1.21 & 0.96 & 0.57 & 0.15 & 6.58 & 7.81 & 1.16 & 94.5 & 13.06 & 0.30 & 0.80 & 0.03 & 9.06 & 7.98 & 35.48 & 65.3 & 27.35 \\
\hline VRSA2 & 1.03 & 5.64 & 0.43 & 0.56 & 10.04 & 6.95 & & & & 0.70 & 0.18 & 0.08 & 8.65 & 6.50 & & & \\
\hline VRSA3 & 0.29 & 1.17 & 0.02 & 0.14 & 8.37 & 6.86 & & & & 0.63 & 0.03 & 0.10 & 6.60 & 6.67 & & & \\
\hline VRSA4 & -0.47 & 0.18 & 0.31 & 0.02 & 8.32 & 7.43 & 3.01 & 99.5 & 15.67 & 4.75 & 0.02 & 0.62 & 7.73 & 6.63 & 28.04 & 60.4 & 26.38 \\
\hline $\mathrm{EE}$ & -0.743 & 0.54 & 0.87 & 0.07 & 7.62 & 7.62 & 1.42 & 78.2 & 14.32 & 0.48 & 0.33 & 0.04 & 12.55 & 7.44 & 4.03 & 65.0 & 26.84 \\
\hline E1 & 0.574 & 0.30 & 0.01 & 0.04 & 7.80 & 7.70 & 0.48 & 106.3 & 14.87 & 0.81 & 0.09 & 0.07 & 12.38 & 7.00 & 35.61 & 68.6 & 28.23 \\
\hline E2 & -0.066 & 0.22 & 0.83 & 0.04 & 5.89 & 7.53 & & & & 0.31 & 0.77 & 0.03 & 10.52 & 7.02 & & & \\
\hline E3 & -0.743 & 0.79 & 0.20 & 0.09 & 8.44 & 7.76 & 1.61 & 91.3 & 14.72 & 0.67 & 0.14 & 0.06 & 12.00 & 6.98 & 22.34 & 83.7 & 29.57 \\
\hline LG1 & 0.397 & 8.17 & 2.00 & 1.05 & 7.78 & 6.44 & & & & 6.66 & 1.21 & 0.90 & 7.37 & 6.50 & & & \\
\hline LG2 & 0.167 & 6.03 & 0.71 & 0.83 & 7.27 & 6.86 & & & & 5.66 & 0.87 & 0.77 & 7.33 & 6.74 & & & \\
\hline LG3 & -0.09 & 2.33 & 0.60 & 0.34 & 6.86 & 7.42 & 27.79 & 69.0 & 13.93 & 3.27 & 0.60 & 0.39 & 8.35 & 7.64 & 35.97 & 44.4 & 25.20 \\
\hline
\end{tabular}

Carbonate content and availability of $\mathrm{CaCO}_{3}$ in the Guadiana Estuary were inferred from TIC variations. TIC values varied from 0 to $2 \%$, with no major differences between winter and summer. No TIC gradation was found in relation to elevation (Tables 1 and 3). This is also in accordance with microscopic observations (unpublished results), which yielded low counts of autochthonous living meiofauna in the upper and middle marshes, although some of the samples of high marsh yielded significant numbers of epifaunal organisms (gastropods). In the lower marshes, both autochthonous meiofauna (live juvenile bivalves, ostracodes and foraminifera) and reworked bioclasts contributed to TIC. Middle marsh samples had the lowest TIC concentrations in both seasons. TIC variation with latitude suggests a seaward gradient, with the lowest values in the upper estuary $(0.17 \%)$ and the highest values in the lower estuary $(0.39 \%)$ (Tables 1 and 3). A moderate positive correlation was found between TIC and salinity (Table 1), only significant in winter.

\subsection{Physicochemical parameters}

Salinity values varied considerably between winter and summer, especially in the lower estuary. In winter, salinity was very low along the entire estuary (0.13 to 3, Fig. 6). Only SCM (a saltworks pond) and LG3 (a tidal pond) presented higher values, 14.3 and 27.8 , respectively. In summer, no major differences were found in the mid- upper estuary, in which values remained lower than 1 for all samples. However, from the FB3 site towards the mouth, salinity tended to increase gradually, reaching normal seawater values at the southernmost site LG3 (Fig. 6). All the confined sites (SCM, VRSA1, E1 and LG3) exhibited high salinities during summer, varying from 26 to 36, at SCM and LG3, respectively. Site EE retained a low salinity value (Table 3) due to continuous freshwater flow from the Ayamonte Sewage Treatment Plant (ASTP). Wastewater influx may influence salinity in the southern areas of the estuary, since the E3 site also registers a lower salinity than the sample immediately upstream.

The dissolved oxygen (DO) signal exhibited considerable seasonal differences. In winter, DO values were higher, varying from 69 to $115 \%$, and lower in summer, varying from 35 to $92 \%$ (Fig. 6 and Table 3). These differences were more evident in the lower estuary. In both seasons there was upstream increase in DO (Fig. 6). Thus, DO exhibits an opposing trend to salinity that is more evident in summer $(\mathrm{R}=-0.70)$.

Unsurprisingly, the temperature (T) signal is quite different in winter and summer (Fig. 6). In winter the values varied between 12.4 and $15.7^{\circ} \mathrm{C}$, whereas in summer values ranged from 20.2 to $29.6^{\circ}$ C. A moderate negative correlation was observed between $\mathrm{T}$ and elevation in both seasons, significant only in winter (Table 1). 


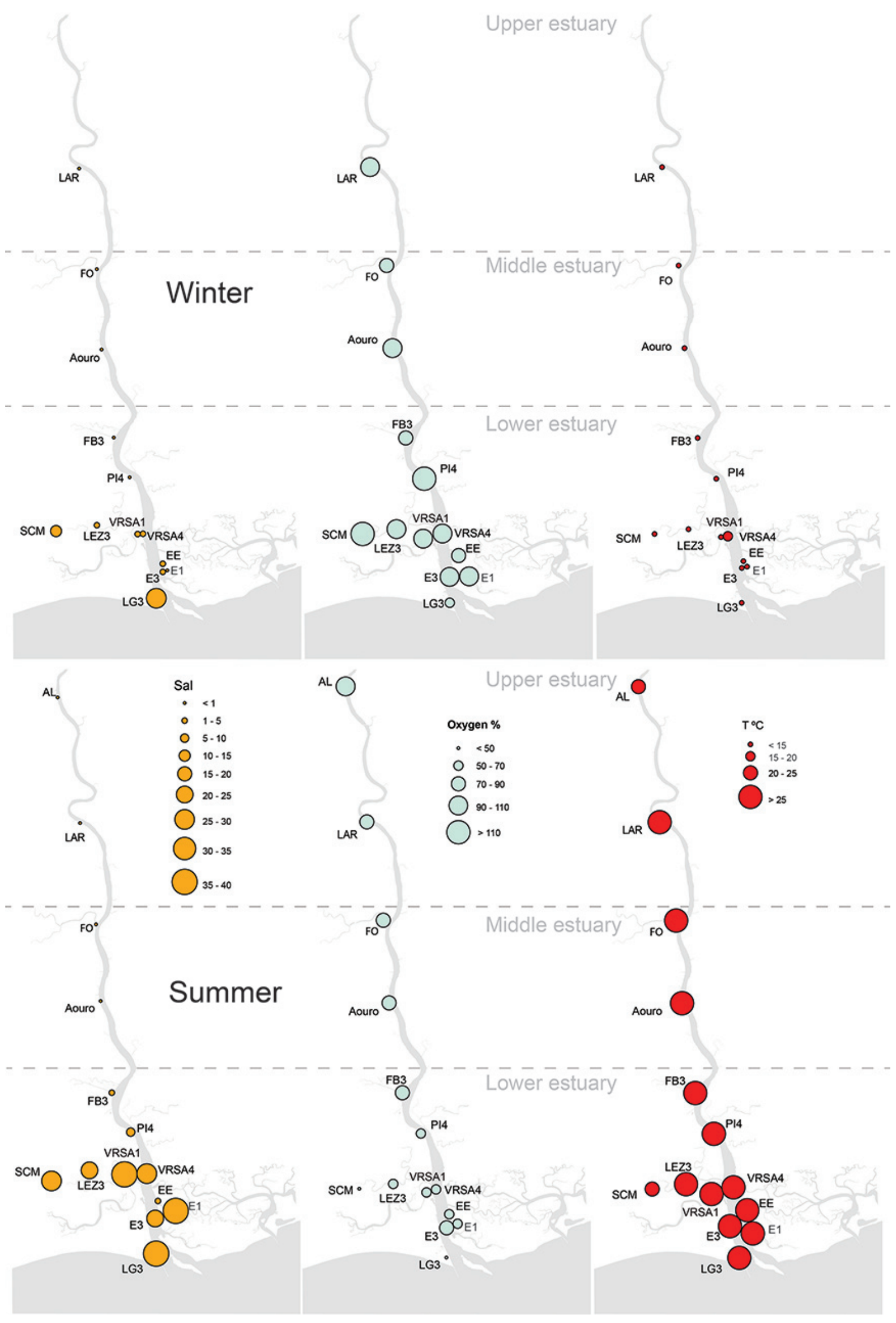

Figure 6. North-south variation of salinity, dissolved oxygen $(\%)$ and temperature $\left({ }^{\circ} \mathrm{C}\right)$ along the Guadiana Estuary during winter and summer.

Figura 6. Variação Norte/Sul dos valores de salinidade, oxigénio dissolvido (\%) e temperatura $\left({ }^{\circ} \mathrm{C}\right)$ ao longo do Estuário do Guadiana, durante o Inverno e Verão. 
Temperature correlated negatively with both TOC and TN. These covaried and were positively correlated with elevation and especially with mud content (Table 1). Despite the strength of the relationship between T, TOC and TN, it seems that these variables are independent and that their inverse relationship stems from $\mathrm{T}$ relationships with elevation, which in turn, control TOC and TN content.

Temperature exhibited a negative correlation with latitude and positive with salinity, although not significant in either seasons (Table 1). Temperature relationships with DO differed in winter (negative) and summer (positive).

Although exhibiting similar ranges of variation in both seasons, $\mathrm{pH}_{\text {sed }}$ values were slightly higher in winter (Table 3). No significant relationship was found between $\mathrm{pH}_{\text {sed }}$ and DO, although the negative correlation (Table 1). There was no obvious $\mathrm{pH}_{\text {sed }}$ gradient in relation to marsh elevation, although the lowest values were always found in the midupper marshes and the highest values in the lower marshes. Again, the upper marsh sample VRSA1 was an outlier, having the highest $\mathrm{pH}_{\text {sed }}$ in both seasons.

During both seasons there was a negative correlation between $\mathrm{pH}_{\text {sed }}$ and mud content, TOC and TN (Table 1).

\section{DISCUSSION}

\subsection{Physicochemical proxies}

Except for $\mathrm{pH}_{\text {sed' }}$ physicochemical parameters varied strongly seasonally, especially in the lower estuary. Observed salinity variations are in accordance with those of other authors (Dias et al., 2001; Garel et al., 2009; Rocha et al., 2002), who identified a salt wedge in the lower estuary during winter and freshwater dominance during high flows. During summer, river flows are negligible and the estuary is tidally dominated, causing strong vertical mixing of salinity during spring tides and strong saline intrusion during neap tides (Rocha et al., 2002). The extension of saline intrusion depends on tidal phase (Dias et al., 2001). In the present work, significant saline intrusion (2.8) was observed until FB site (Beliche Rivulet, $\approx 8 \mathrm{~km}$ from the river mouth) during a low spring-tide phase. For the same distance and same tide phase, a similar value $(\approx 3 \%$ ) was found by Michel and Wollast (1978) prior to the construction of the biggest dams (November, 1977). Their detailed measurements showed that saline intrusion was still significant $3 \mathrm{~km}$ upstream of the FB site.

Dissolved oxygen (DO) concentrations were higher in winter and upstream. Temperature was higher in summer but had no significant relationship with latitude. The opposing trends observed between DO and temperature are in agreement with Garel and Ferreira's (2011) data, which show opposite trends in the same tidal phase during different seasons. In other words, during the ebb phase, $\mathrm{T}$ decreased and oxygen increased in winter, whilst $\mathrm{T}$ increased and oxygen decreased in summer.

The most extreme seasonal variations were observed in the confined waterlogged areas in the high marsh zone. In winter, when the contribution of river water and rainwater is higher, low salinities, high oxygen values and low temperatures are characteristic. In summer, when insolation and evaporation are the most important factors, salinity increases, oxygen decreases and temperature increases.
Sediment $\mathrm{pH}$ exhibited lower seasonal variation than other proxies, with a slight increase in winter. Values were not as high as would be expected for seawater (7.4 to 8.4), nor as low as for river water (ca. 5) (Suguio, 2003). In sediment, $\mathrm{pH}$ reflects a mixture of both saltwater and freshwater inputs, as well as the quantity of organic matter present. Marsh sediments are rich in organic matter, especially from halophytic vegetation, which, along with bioactivity, promotes reducing conditions (Suguio, 2003). Phleger and Bradshaw (1966) found a positive relationship between $\mathrm{pH}_{\text {sed }}$ and oxygen in a diurnal cycle, being strongest during daytime, when marsh plants are producing oxygen, and during flood tide, when high $\mathrm{pH}$, highly oxygenated water is being introduced from the sea. In the present work, DO values were highest during winter, although a negative, nonsignificant relationship was found between $\mathrm{pH}_{\text {sed }}$ and DO. Garel and Ferreira (2011) found diurnal and tidal factors are the major forcing factors linking water $\mathrm{pH}$ and oxygen. However, this trend is invalided when river flow plays a part. For periods of high freshwater (oxygen-saturated) discharge, oxygen increases substantially and $\mathrm{pH}$ values decrease abruptly (Garel and Ferreira, 2011).

During both seasons there was a negative relationship between elevation, TOC, TN and mud content with $\mathrm{pH}_{\text {sed }}$. This is expected due to the yield strength and viscosity of cohesive sediments (Sornin, 1983), entrapping organic matter that in turn is decomposed by microbial activity, increasing reduction potential (Bale and Kenny, 2005).

The present study shows that the physicochemical parameters are intrinsically related and that their variations are strongly dependent in seasonal and spatial patterns. Recent modeling predicts that summer drought scenarios will be exacerbated (Santos et al., 2002). Under these conditions, higher water temperature, higher salinities and lower oxygen concentrations are expected, such as was evident in our summer data set. Such strong seasonal differentiation can affect biochemical processes and trophic structure, with impacts on the abundance, biomass and distribution of fish assemblages (Chícharo et al., 2006b), and general biodiversity changes, with some native species being replaced by non-native species adapted to the low flow, warmer conditions (Chícharo et al., 2009; Encarnação et al., 2013; Morais, 2008; Morais et al., 2009b).

\subsection{Sediment dynamics}

The present data point to a slight increase in the proportion of coarser sediments in the estuary during winter, especially in the lower estuary. In a bedrock-controlled estuary such as the Guadiana, a seaward sediment-size gradient is to be expected due to the energetic textural bipolarity (river $x$ tidal/sea energy), in which fluvial sediment is reworked from the river to the sea by ebb currents and flood currents introduce marine sediment into the estuary (Morales et al., 2006). During tidal cycles, fluvial sediments are mixed with marine sediments in the lower estuarine channel, where active sedimentation takes place on the lateral bars (Morales et al., 1997; 2006). This process is most pronounced on the left margin (Spanish side), where the channel is shallower (probably with lower velocity currents) and overwash 
deposits are visible. This may explain the incidence of gravel-bioclast deposits in samples from the Spanish side, especially in summer when the hydrodynamic processes are predominantly sea-dominated (Machado et al., 2007). The poor sorting of the sediments deposited in the marsh banks is related to changes in energy resulting from different tidal conditions as well as seasonal hydrodynamics (Dias et al., 2001), whereas skewness, which ranges between symmetrical to very fine skewed, reflects the efficiency of fine-fraction transport from the banks to the water.

The upper marsh zone (1-2 m) comprises muddy sediments, composed mostly of silts, which are transported in suspension by the river. Fine sediment is deposited in the upper marsh (during the flood peak) where the hydrodynamism is reduced and tidal currents and wind waves are buffered by dense halophytic vegetation (Sen Gupta, 1999). The upper marshes are then flood-dominated, promoting vertical accretion and therefore decreasing the export of fine sediment to the ocean. Since mud is quite resistant to erosion due to its high yield strength and viscosity (Sornin, 1983), continuous sedimentation during tides that overtop the marsh banks contributes to extending the muddy margins across the alluvial plain.

Mid and low marshes have an increasingly sandy composition, meaning that they are ebb dominated with efficient seaward export of fine sediments. Additionally, the vegetation of these zones is sparse (mainly composed by Spartina maritima) or absent, and therefore less effective in dissipating current energy, which increases with the proximity to the bypassing subtidal zone (Morales et al., 2006; Dias et al., 2001). Coarser granulometry and exposure to tidal currents combine to promote erosion rather than deposition in this zone. Hydro-sedimentary processes within the estuary are the consequence of the balance between freshwater discharge (spring freshets), tidal currents and sediment supply and can therefore be modified by climatic changes, sea-level fluctuations and human action. Our observations suggest that, during wet seasons, when larger amounts of water carrying fluvial sediments are released into the estuary, the dominant hydrodynamic conditions are not conducive to sediment deposition and marsh accretion. On the other hand, artificial regulation is preventing the occurrence of the typical freshets responsible for the washing out of coarser sediments into the continental shelf. Instead, these sediments are accumulating at the mouth of the estuary. During the dry season, although the low hydrodynamic conditions enable sediment deposition due to the increased residence time of the particles (Machado et al., 2007), suspended sediment input is low. Since the Alqueva Dam was commissioned, freshwater discharge into the estuary has remained low throughout the year (generally $<20 \mathrm{~m}^{3} \mathrm{~s}^{-1}$ ) (Garel and Ferreira, 2011). During the dry season this scenario is aggravated with frequent nil discharges (SNIRH, 1995-2014) and negligible fine sediment deposition in saltmarsh zones. During this season the estuary is essentially dominated by tidal forcing, with increment of fine (ilite) and coarser sediments (quartz) related to the entrance of saline water during flood periods (Machado et al., 2007). Marsh erosion during flood events, accumulation of coarser sediments in the river mouth (of both fluvial and marine origin) and fine sediment starvation contribute to a disequilibrium of both vertical and horizontal deposition, changing the topography of the estuary and its hydrodynamic processes, especially the velocity of the ebb/flood tides (Healey et al., 1981) and the tidal prism (D'Alpaos et al., 2006). This effect causes, in turn, impact on the ecological balance of the estuary. Sediment starvation and erosion will alter the density and composition of the halophytic vegetation which, consequently, plays an essential role in the sedimentation process, retarding currents and promoting retention of suspended sediments (Costa, 2001). The expected long-term trend will be the disappearance of marshes, with knock-on effects on ecosystems, economic activities and tourism potential.

\subsection{Sedimentary organic matter and carbonates}

The origins, pathways and fates of sedimentary organic material within an estuary can be useful in the reconstruction of the paleo-hydrodynamic processes involved in the estuary formation. Organic matter and sedimentological parameters are often used as important proxies for saltmarsh evolution (e.g., Boski et al., 2002, 2008; Drago et al., 2004; Freitas et al., 2002; González-Vila et al., 2003; Schuerch et al., 2012). Decreasing TOC content from upper to lower elevations is strongly related to tidal circulation patterns (Suguio, 2003), which promote marked differences in vegetation zonation, water circulation velocities and, consequently, sediment granulometry. In the marginal sediments of the Guadiana Estuary, the highest TOC values were observed in the upper marshes, where hydrodynamics are reduced, vegetation is abundant and the sediments are finer, cohesive, less porous and consequently, less permeable. In the lower marshes, higher sand content increases porosity, allowing efficient water circulation and enabling resuspension and oxidation of deposited organic matter. These relationships between elevation, grain size and organic matter have also been observed in other estuarine environments around the world (CSIRO, 2000; Goñi et al., 2003; Middelburg et al., 1997; Zhou et al., 2007). In the Guadiana Estuary, the relationship between TOC and elevation may be enhanced during winter due to stronger hydrodynamics in the estuary, promoting more efficient sorting of both organic matter and sediments.

The homogeneous $\mathrm{C} / \mathrm{N}$ ratios (usually between 6 and 12 ) found along the estuary suggests that organic matter is largely controlled by mixing of aquatic (autochthonous $-\mathrm{C} / \mathrm{N}=$ 6-9) and terrestrial end members $(\mathrm{C} / \mathrm{N}=9-12)$. A higher contribution was expected from saltmarsh vascular plants as they are reported to be the dominant sources of organic matter in these ecosystems (Canuel et al., 1997). Nevertheless, $\mathrm{C} / \mathrm{N}$ values typical of marsh plants are much higher (Zhou et al., 2006) than those found in the sediments of Guadiana Estuary, suggesting that the contribution from marsh plants is relatively low and that the main source of sedimentary organic matter is aquatic. This trend had been earlier observed by other authors (Boschker et al., 1999; Canuel et al., 1997; Ember et al., 1987). The inverse relationship between $\mathrm{C} / \mathrm{N}$ and elevation observed in both seasons can be explained by the hydrodynamic conditions and sediment properties. According to Meyers (1997), different sediment 
size-fractions typically have different $\mathrm{C} / \mathrm{N}$ ratios, with coarse sediment fractions containing a larger proportion of intact land-plant debris than fine fractions, thereby having elevated $\mathrm{C} / \mathrm{N}$ ratios. Furthermore, fine sediment fractions contain a larger proportion of clay minerals, which have large surface areas and negative surface charges. Clays therefore adsorb ammonia well, and this may depress their $\mathrm{C} / \mathrm{N}$ ratios due to the uptake of inorganic nitrogen (Meyers, 1997). In wet seasons, the hydrodynamics are stronger, promoting more efficient export of particulate organic matter from the estuary (Oliveira et al., 2006). In dry seasons (summer), hydrodynamic processes are weakened and the residence time of the particulate organic detritus at lower elevations is increased, leading to temporarily increased $\mathrm{C} / \mathrm{N}$ ratios. High values of $\mathrm{C} / \mathrm{N}$ ratio in the Guadiana's lower marshes during summer could also be related to the proximity of the ASTP, which could be contributing with cellulose-rich allochthonous biomass.

$\mathrm{C} / \mathrm{N}$ had a positive, relatively strong correlation with latitude in winter $(R=0.71)$, with the highest values in the northernmost samples, but the same relationship was not evident in summer. Despite seasonal differences, a consistent picture emerges of organic material being derived largely from terrestrial sources in the mid-upper estuary and upper marsh zones of the lower estuary, whereas a substantial input of autochthonous aquatic material occurs in the mid-lower marsh zones of the lower estuary.

Dyer (1990) showed that bioclastic materials in estuaries have various origins, resulting from the local fauna or sediment transport. In the present work, the highest TIC values were found in the least hydrodynamic environments (which are more suitable for fauna fixation and carbonate particle accumulation) and at lower elevations (where autochthonous infaunal organisms are found alongside reworked bioclastic material, which accumulates in sorted deposits under the moderate hydrodynamic conditions).

The highest TIC content is concentrated in the lower estuary. This relationship is expected if $\mathrm{pH}$ differences in river and sea waters are considered along a salinity gradient. Carbonates, in particular calcite, precipitate in alkaline waters ( $\mathrm{pH}>7$, typical of seawater), whereas calcite dissolves in acidic water $(\mathrm{pH}<6$, typical of freshwater) (Suguio, 2003). Indeed, a moderate positive relationship was found between TIC and salinity (Table 1), although only significant in winter. Correlations between TIC, latitude and salinity may be attenuated during summer due to higher availability of $\mathrm{CaCO}_{3}$ when temperature and salinity are higher along the estuary (Buzas, 1989).

\subsubsection{Comparison with previous studies}

The sediments of saltmarsh ecosystems of the Guadiana Estuary are poorly documented and little is known about the origins of the sedimentary organic matter. Most previous studies of estuarine systems in the Gulf of Cadiz have focused on biogeochemistry in relation to heavy metals and other sources of pollution (e.g., Borrego et al., 2002; Gonzalez et al., 2006; Delgado et al. 2010).

In the sediments of the Guadiana Estuary, TOC values were highly variable and relatively high compared to other estuaries and other coastal environments described in literature (Table 4). The Guadiana values are, however, similar to those found in other river dominated estuaries (CSIRO, 2000; Goñi et al., 2003) (Table 4). TN content, which is considered indicative of the contribution of aquatic flora (González-Vila et al., 2003), was higher and more variable than those found in other estuarine systems (Table 4). The high variability in TOC and TN content in Guadiana sediments reflects the great diversity of the sampled sub-environments, which are subject to various physicochemical conditions, among which hydrodynamics, grain size and topography play major roles. Homogenous $\mathrm{C} / \mathrm{N}$ values suggest that the existing organic matter results from an even contribution of terrestrial and autochthonous aquatic (primary producers) sources. TOC and TN values found in Guadiana sediments are very similar to those found in the mesotrophic Huon Estuary (CSIRO, 2000). Brito et al. (2012), who assessed the ecological status of several Portuguese estuaries based on phytoplankton biomass (chlorophyll $a$ ) and phytoplankton blooms (historical data - 1992 to 2010), considered the Guadiana as the most problematic estuary among the twelve studied, with waters classified from High to Poor Ecological Status. However, in a recent study concerning the period after Alqueva filling (2004-2009), Domingues et al. (2014) observed a decline in chlorophyll $a$ and phytoplankton, including cyanobacteria, in relation to the periods before and during the dam filling suggesting an oligotrophic tendency. The authors relate this trend to river regulation causing higher and constant flows during the productive period (summer). The studied year (2010) had one of the highest flow summers since Alqueva was commissioned (2005 to 2012), with a mean flow of 52 $\mathrm{m}^{3} / \mathrm{s}$ (station $26 \mathrm{~L} / 01 \mathrm{H}$, SNIRH, 1995-2014). In drought years, however, summer discharges are virtually nil (e.g., 2012, SNIRH, 1995-2014). Under these low-flow conditions, the risk of eutrophication is higher, i.e., chlorophyll $a$, green algae and cyanobacterial abundance increases (Barbosa $e t$ al., 2010). Whilst nutrient concentrations are still considered as the primary determinant of eutrophication in estuaries, many other factors are recognized as important (Bricker et al., 2003). Most diagnostic variables relate to water and subtidal benthic environments and little attention has been given to intertidal wetlands. The present data provide an overall picture of the main sources of organic matter in the Guadiana Estuary in a particularly wet year and alone are not extensive enough to determine the trophic level of the estuary. Further work would be required to fully understand the differences between the trophic responses of sediments in relation to water. Seasonal time-series are recommended, with special attention to dry years, which resemble the most critical future climate scenarios: longer and more frequent droughts, reduced precipitation and, consequently, reduced river runoff are all forecast for the area (Cunha et al., 2002; Miranda et al., 2002). The study of stable isotopes and other biomarkers should be considered in order to determine the signatures of a wider range of potential organic matter sources (e.g., the remains of living-in-sediment animals) and to identify the links between water column and sediment processes. 
Table 4. Comparison of TOC, TN and C/N values for the Guadiana intertidal margins and other coastal regions worldwide (the high degree of variability in TOC within and between estuaries should be kept in mind when comparing our results to those of previous studies).

Tabela 4. Comparação entre os valores de COT, NT e C/N das margens intermareais do Guadiana e de outras regióes costeiras do mundo (o elevado grau de variabilidade dos valores de COT dentro e entre estuários deve ser considerado quando comparamos os presentes dados com aqueles dos estudos anteriores).

\begin{tabular}{c|c|c|c|c}
\hline Study area & TOC $(\%)$ & TN $(\%)$ & C/N & Reference \\
\hline $\begin{array}{c}\text { Guadiana saltmarshes, Portugal } \\
\text { Land van Saaftinghe saltmarshes, } \\
\text { Netherlands }\end{array}$ & $0.2-9$ & $0.02-1.1$ & $5.9-15.3$ & This study \\
\hline Pearl River Estuary, China & $0.06-1.02$ & $0.03-0.19$ & $1.8-9.1$ & Hieuwenhuize et al., 1994 et al., 2006 \\
\hline Yangtze salt-marshes, China & $0.1-0.7$ & $0.014-0.078$ & $5.7-11.3$ & Zhou et al., 2007 \\
\hline Huon Estuary, Tasmania & $0.2-9.6$ & $0.01-0.74$ & $2.9-31$ & CSIRO, 2000 \\
\hline Winyah Bay, SC, USA & $0.05-7.62$ & $0.01-0.4$ & - & Goñi et al., 2003 \\
\hline Other coastal environments & $0.1-2.12$ & $0.03-0.17$ & - & Nieuwenhuize et al., 1994 \\
\hline
\end{tabular}

\section{CONCLUSIONS}

In the Guadiana Estuary, variation in geochemical and sedimentological parameters was found to be very dependent on distance to sea and elevation energy gradients, which in turn are dependent on the different seasonal periods, with riverine conditions prevailing during winter and marine and tidal conditions prevailing during summer. Intertidal sediments vary from fine silt to medium sand, with increasing average grain-size from the upper marsh zones to lower zones. Sediments are generally poorly sorted, with a symmetrical to very finely skewed distribution, in accordance with the lowenergy conditions typical of the deposition areas. The 2010 winter was particularly rainy, forcing continuous discharge from Alqueva dam, which contributed to increasingly coarse sediment deposition in the estuary, particularly in the less elevated stands.

In summer, the estuary waters were better mixed and significant saltwater intrusion was detected $8 \mathrm{~km}$ upstream the mouth.

Confined waterlogged areas were subject to extreme seasonal variations in salinity and dissolved oxygen. In winter, when the contribution of river and rainwater is higher, lower salinities and higher oxygen concentration were observed. Conversely, in summer when insolation and evaporation are the most important factors, salinity increases and oxygen decreases.

There was a dependent relationship between elevation and organic matter, $\mathrm{pH}$ and particle size. In the higher marsh zones, with lower hydrodynamics, differential deposition of fine sediments occurs. These cohesive sediments trap organic matter and its subsequent degradation lowers $\mathrm{pH}$.

Sedimentary organic matter in the Guadiana is derived from a mixture of native aquatic and terrestrial sources. Organic material in the mid-upper estuary areas and higher saltmarsh zones of the marine estuary incorporates more terrestrial material, whereas a substantial contribution from indigenous aquatic sources occurs at low-middle zones of the marine estuary.

The present data provide the baseline environmental characterization of a regulated estuarine system still in 'ecological control'. This information is useful for paleoenvironmental studies, environmental monitoring and for integrated coastal zone management in the southern Iberian Peninsula, especially given the complex interactions between estuarine sedimentation, coastal erosion, sea levels, river regulation and human settlements in the Guadiana Estuary. Although 2010 was an exceptionally wet year, with summer discharges controlled by continuous water release, the differences between environmental seasonal scenarios are clearly marked, demonstrating the potential for major changes if climate change predictions for this region are fulfilled. Seasonal time-series studies are needed to better understand the sources, pathways and fates of the sedimentary organic matter and to establish the links between these processes and water-column processes. These results should be compared with those from other estuaries located at the same climatic region to enhance the robustness of climate predictive assessments.

\section{ACKNOWLEDGEMENTS}

The authors would like to thank to Laura Pereira, Paulo Santana and Selma Gabriel for technical assistance with field survey and Eduardo Soares for is friendliness and for lend is boat in difficult times. We are also grateful to João Horta for cartography and GIS assistance. We would also like to thank to Dr Virgínia Martins and two anonymous reviewers, whose comments greatly improved the original manuscript. The present work was financially supported by the Portuguese Foundation for Science and Technology (FCT) through PhD grant SFRH/BD/28265/2006. 


\section{REFERENCES}

Bale, A.J.; Kenny, A.J. (2005) - Sediment Analysis and Seabed Characterization. In: Eleftheriou, A., McIntyre, A. (ed), Methods for the Study of Marine Benthos, 3rd edition, pp. 43-86, Blackwell Science, . ISBN 0-632-05488-3.

Barbosa, A.M.; Domingues, R.; Galvão, H. (2010) - Environmental Forcing of Phytoplankton in a Mediterranean Estuary (Guadiana Estuary, SouthWestern Iberia): A Decadal Study of Anthropogenic and Climatic Influences. Estuaries and Coasts, 33(2):324-341. DOI: $10.1007 / \mathrm{s} 12237-009-9200-\mathrm{x}$

Blott, S.J.; Pye, K. (2001) - GRADISTAT: a grain size distribution and statistics package for the analysis of unconsolidated sediments. Earth Surface Processes and Landforms, 26(11):1237-1248. DOI: 10.1002/esp.261

Bordovskiy, O.K. (1965) - Accumulation and transformation of organic substances in marine sediments. Marine Geology (ISSN: 0025-3227), 3(1-2):3-114. DOI: 10.1016/00253227(65)90002-2

Borrego, J.; Morales, J.; de la Torre, M.; Grande, J. (2002) - Geochemical characteristics of heavy metal pollution in surface sediments of the Tinto and Odiel river estuary (southwestern Spain). Environmental Geology, 41(7):785796. DOI: $10.1007 / \mathrm{s} 00254-001-0445-3$

Boschker, H.; de Brouwer, J.; Cappenberg, T. (1999) - The contribution of macrophyte-derived organic matter to microbial biomass in salt-marsh sediments: Stable carbon isotope analysis of microbial biomarkers. Limnology and Oceanography, 44(2):309-319. DOI: 10.4319/ lo.1999.44.2.0309

Boski, T.; Moura, D.; Veiga-Pires, C.; Camacho, S.; Duarte, D.; Scott, D.B.; Fernandes, S. (2002) - Postglacial sea-level rise and sedimentary response in the Guadiana Estuary, Portugal/Spain border. Sedimentary Geology, 150(12):103-122. DOI: 10.1016/S0037-0738(01)00270-6

Boski, T.; Sousa, C.; Loureiro, C.; Limpo, S.; Albardeiro, L.; Camacho, S.; Pereira, L.; Amaral, A.; Nieto, J.; Rodriguez, J.; Salas, L.; Gonzalez-Vila, F.; Pérez, J.; Simonson, W.; Lima, A. (2006) - GUADID, version 1.1, How an estuary works? Didactic Application: Project MEGASIG, Faro, Portugal. Available at http://aljarafe.net/megasig/pt/ index.html

Boski,T.; Camacho, S.; Moura, D.; Fletcher, W.; Wilamowski, A.; Veiga-Pires C.; Correia, V.; Loureiro, C.; Santana, P. (2008) - Chronology of the sedimentary processes during the post-glacial sea level rise in two estuaries of the Algarve coast, southern Portugal. Estuarine, Coastal and Shelf Science, 77(2):230-244. DOI: 10.1016/j. ecss.2007.09.012.

Bricker, S.B.; Ferreira, J.G.; Simas, T.; (2003) - An integrated methodology for assessment of estuarine trophic status. Ecological Modelling, 169(1):39-60. DOI: 10.1016/ S0304-3800(03)00199-6.

Brito, A.; Brotas, V.; Caetano, M.; Coutinho, T.; Bordalo, A.; Icely, J.; Neto, J.; Serôdio, J.; Moita, T. (2012) Defining phytoplankton class boundaries in Portuguese transitional waters: An evaluation of the ecological quality status according to the Water Framework Directive. Ecological Indicators, 19:5-14. DOI: 10.1016/j. ecolind.2011.07.025.
Bromwich, D., Nicolas, J., Monaghan, A., Lazzara, M., Keller, L., Weidner, G. and Wilson, A. (2013) - Central West Antarctica among the most rapidly warming regions on Earth. Nature Geoscience, 6:139-145. DOI: 10.1038/ NGEO1671

Buzas, M.A. (1989)- The effect of quartz versus calcareous sand on the densities of living foraminifera. Micropaleontology (ISSN: 0026-2803), 35(2):135-141, Washington, DC, U.S.A. Available at http://si-pddr.si.edu/dspace/bitstrea $\mathrm{m} / 10088 / 7414 / 1 / 230$ Buzas1989Micropal.pdf

Canuel, E.; Freeman, K.; Wakeham, S. (1997) - Isotopic compositions of lipid biomarker compounds in estuarine plants and surface sediments. Limnology and Oceanography (ISSN 0024-3590), 42(7):1570-1583. Available at http:// aslo.org/lo/toc/vol_42/issue_7/1570.pdf

Chícharo, L.; Chícharo, M.A.; Radhouane, B-H. (2006a) Use of a hydrotechnical infrastructure (Alqueva Dam) to regulate planktonic assemblages in the Guadiana estuary: Basis for sustainable water and ecosystem services management. Estuarine, Coastal and Shelf Science, 70(12):3-18. DOI: 10.1016/j.ecss.2006.05.039.

Chícharo, M.A.; Chícharo, L.; Morais, P. (2006b) - Interannual differences of ichthyofauna structure of the Guadiana estuary and adjacent coastal area (SE Portugal/ SW Spain): Before and after Alqueva dam construction. Estuarine, Coastal and ShelfScience, 70(1-2):39-51. DOI: 10.1016/j.ecss.2006.05.036.

Chícharo M.A.; Leitão T.; Range P.; Gutierrez C.; Morales J.; Morais P.; Chícharo, L. (2009) - Alien species in the Guadiana Estuary (SE-Portugal/SW-Spain): Blackfordia virginica (Cnidaria, Hydrozoa) and Palaemon macrodactylus (Crustacea, Decapoda): potential impacts and mitigation measures. Aquatic Invasions, 4(3):501506. DOI: 10.3391/ai.2009.4.3.11.

Church, J.A.; White, N.J. (2006) - A 20th century acceleration in global sea level rise, Geophysical Research Letters, 33(1):1-4. DOI: 10.1029/2005GL024826.

Confederación Hidrográfica del Guadiana (2012) Catálogo de metadatos. In: Geoportal Guadiana [web page], Confederación Hidrográfica del Guadiana, Badajoz, España. Available at http://www.chguadiana.es/ serviciocsw/

Costa, J.C. (2001) - Tipos de vegetação e adaptaçôes das plantas do litoral de Portugal continental. In: M. E. Moreira, A. Moura, H. M. Granja \& F. Noronha (eds.) Homenagem (in honorio) Professor Doutor Soares de Carvalho, pp. 283-299, Universidade do Minho, Braga, Portugal. Available at http://www.isa.utl.pt/files/pub/ ensino/cdocente/Adaptacoes_Plantas.pdf

Cravo, A.; Madureira, M.; Felícia, H.; Rita, F.; Bebianno, M-J. (2006) - Impact of outflow from the Guadiana River on the distribution of suspended particulate matter and nutrients in the adjacent coastal zone. Estuarine, Coastal and Shelf Science, 70(1-2):63-75. DOI: 10.1016/j. ecss.2006.05.034.

CSIRO Huon Estuary Study Team (2000) - Huon Estuary Study - environmental research for integrated catchment management and aquaculture. 285p., Final report to Fisheries Research and Development Corporation, Project number 96/284, CSIRO Division of Marine Research, 
Hobart, TAS, Australia. ISBN: 0643062254. Available at http://www.cmar.csiro.au/research/huonestuary/report/ CSIRO_FRDC_HuonEstuaryStudy2000.PDF

Cunha, L.; Oliveira, R.; Nunes, V. (2002) - Water resources. In: F. Santos, K. Forbes \& R. Moita. (eds.), Climate change in Portugal. Scenarios, impacts and adaptation measures SIAM Project, pp.135-171, Gradiva, Lisboa. Available at http://siam.fc.ul.pt/siamI_pdf/SIAM\%20I\%20BOOK/

D’Alpaos, A.; Lanzoni, S.; Mudd, S.; Fagherazzi, S. (2006) - Modelling the influence of hydroperiod and vegetation on the cross-sectional formation of tidal channels. Estuarine, Coastal and Shelf Science, 69(3-4):311-324. DOI: 10.1016/j.ecss.2006.05.002.

Delgado, J.; Nieto, J.; Boski, T. (2010) - Analysis of the spatial variation of heavy metals in the Guadiana Estuary sediments (SW Iberian Peninsula) based on GIS-mapping techniques. Estuarine, Coastal and ShelfScience, 88(1):7183. DOI: $10.1016 /$ j.ecss.2010.03.011.

Dias, J.A.; Ferreira, Ó. (coord.) (2001) - Projecto EMERGE Estudo multidisciplinar do estuário do Rio Guadiana. Relatório final 3/01. CIACOMAR, Universidade do Algarve, Olhão, Portugal. Available at http://w3.ualg.pt/ jdias/JAD/ebooks/ EMERGE/EMERGE_total_red.pdf

Dias, J.; Gonzalez, R.; Ferreira, Ó. (2004) - Natural versus anthropic causes in variations of sand export from river basins: an example from the Guadiana River mouth (Southwestern Iberia). Polish Geological Institute Special Papers (ISSN: 1507-9791), 11:95-102, Warsaw, Poland. Available at http://w3.ualg.pt/\%7Ejdias/JAD/papers/04_ Polish_JAD.pdf

Dias, J.; do Carmo, J.; Polette, M. (2009) - As Zonas Costeiras no contexto dos Recursos Marinhos / The Coastal Zones in the Context of the Marine Resources. Revista de Gestão Costeira Integrada / Journal of Integrated Coastal Zone Management, 9(1): 3-5. DOI: 10.5894/rgci168

Domingues, C.M.; Church, J.A.; White, N.J.; Gleckler, P.J.; Wijffels, S.E.; Barker, P.M.; Dunn, J.R. (2008) - Improved estimates of upper-ocean warming and multi-decadal sea-level rise. Nature, 453:1090-1093. DOI: $10.1038 /$ nature 07080 .

Domingues, R.; Barbosa, A.; Galvão, H. (2005) - Nutrients, light and phytoplankton succession in a temperate estuary (the Guadiana, south-western Iberia). Estuarine, Coastal and Shelf Science, 64(2-3):249-260. DOI: 10.1016/j. ecss.2005.02.017.

Domingues, R.; Sobrino, C.; Galvão, H. (2007) - Impact of reservoir filling on phytoplankton succession and cyanobacteria blooms in a temperate estuary. Estuarine, CoastalandShelfScience, 74(1-2):31-43. DOI: 10.1016/j. ecss.2007.03.021

Domingues, R.; Barbosa, A.; Sommer, U.; Galvão, H. (2012) - Phytoplankton composition, growth and production in the Guadiana estuary (SW Iberia): Unraveling changes induced after dam construction. Science of the Total Environment, 416:300-313. DOI: 10.1016/j. scitotenv.2011.11.043.

Domingues, R.; Barbosa, A.; Galvão, H. (2014) - Impacts of river damming on estuarine phytoplankton: the Guadiana estuary case study. Estuarine, Coastal and Shelf Science, 136:129-138. DOI: 10.1016/j.ecss.2013.11.012
Drago, T.; Freitas, C.; Rocha, F.; Cachão, M.; Moreno, J.; Naughton, F.; Fradique, C.; Araújo, F.; Silveira, T.; Oliveira, A.; Cascalho, J.; Fatela, F. (2004) - Paleoenvironmental Evolution of Estuarine Systems during the Last 14000 Years - the Case of Douro Estuary (NW Portugal). Journal of Coastal Research (ISSN 0749-0208), SI39:186192. Brasil. Available at http://onlinebiblio.lneg.pt/ multimedia/associa/base $\% 20 \mathrm{mono} / 34836$.pdf

Dyer, K.R. (1990) - Coastal Estuarine Sediment Dynamics. 342p. John Wiley \& Sons Ltd., Chichester, UK. ISNB: 0471908762.

Ember, L.; Williams, D.; Morris, J. (1987) - Processes that influence carbon isotope variations in salt marsh sediments. Marine Ecology Progress Series (ISSN: 01718630), 36:33-42. Available at http://www.int-res.com/ articles/meps/36/m036p033.pdf

Encarnação, J.; Leitão, T.; Morais, P.; Piló, D.; Range, P.; Chícharo, L.; Chícharo, M.A. (2013) - Effects of interannual freshwater inflow shifts on the community structure of estuarine decapods. Cahiers de Biologie Marine (ISSN: 0007-9723), 54(2):181-189, Roscoff, France. Available athttp://www.sb-roscoff.fr/cbm/article. htm? execution=e6s 1

Faria, A.; Morais, P.; Chícharo, A. (2006) - Ichthyoplankton dynamics in the Guadiana estuary and adjacent coastal area, South-East Portugal. Estuarine, Coastal and Shelf Science, 70(1-2):85-97. DOI: 10.1016/j. ecss.2006.05.032.

Folk, R.L. (1954) - The distinction between grain size and mineral composition in sedimentary-rock nomenclature. Journal of Geology, 62(4):344-359. Article Stable URL: http://www.jstor.org/stable/30065016

Folk, R.L.; Ward, W.C. (1957). Brazos River bar: a study in the significance of grain size parameters. Journal of Sedimentary Petrology, 27(1):3-26.

Freitas, M.C.; Andrade, C.; Cruces, A. (2002) - The geological record of environmental changes in southwestern Portuguese coastal lagoons since the Lateglacial. Quaternary International, 93-94:161-170. DOI: $10.1016 /$ S1040-6182(02)00014-9

Garel, E.; Pinto, L.; Santos, A.; Ferreira, Ó. (2009) - Tidal and river discharge forcing upon water and sediment circulation at a rockbound estuary (Guadiana estuary, Portugal). Estuarine, Coastal and ShelfScience, 84(2):269281. DOI: $10.1007 / \mathrm{s} 00367-009-0147-5$.

Garel, E.; Ferreira Ó. (2011) - Monitoring estuaries using non-permanent stations: practical aspects and data examples. Ocean Dynamics, 61(7):891-902. DOI: 10.1007/s10236-011-0417-4.

Gehrels, W.R.; Woodworth, P.L. (2013) - When did modern rates of sea-level rise start? Global and Planetary Change, 100:263-277. DOI: 10.1016/j.gloplacha.2012.10.020.

Gomes, A.; Witkowski, A.; Dabek, P.; Boski, T.; Moura, D.; Szkornik, K.; Kurzydlowski, K. (2013) - Syvertsenia iberica (Cymatosiraceae): a new estuarine diatom genus characterized by the position of its process. Phytotaxa, 142(1): 25-36. DOI: 10.11646/phytotaxa.142.1.3

Goñi, M.; Teixeira, M.; Perkey, D. (2003) - Sources and distribution of organic matter in a river-dominated estuary (Winyah Bay, SC, USA). Estuarine, Coastal 
and Shelf Science, 57(5-6):1023-1048. DOI: 10.1016/ S0272-7714(03)00008-8.

Gonzalez, R.; Araújo, M.; Burdloff, D.; Cachão, M.; Cascalho, J.; Corredeira, C.; Dias, J.A.; Fradique, C.; Ferreira, J.; Gomes, C.; Machado, A.; Mendes, I.; Rocha, F. (2006) - Sediment and pollutant transport in the Northern Gulf of Cadiz: A multi-proxy approach. Journal of Marine Systems, 68(1-2):1-23. DOI: 10.1016/j. jmarsys.2006.10.007.

González-Vila, F.J.; Polvillo, O.; Boski, T.; Moura D.; Andrés, J. R. (2003) - Biomarker patterns in a time-resolved Holocene/terminal Pleistocene sedimentary sequence from the Guadiana river estuarine area (SW Portugal/ Spain border). Organic Geochemistry, 34(12):1601-1613. DOI: 10.1016/j.orggeochem.2003.08.006.

Healey, R.; Pye, K.; Stoddart, D.; Bayliss-Smith, T. (1981) - Velocity Variations in Salt Marsh Creeks, Norfolk, England. Estuarine, Coastal and Shelf Science, 13(5):535545. DOI: $10.1016 / S 0302-3524(81) 80056-4$

Hearn, C.J. (1998) - Application of the Stommel model to shallow Mediterranean estuariesand their characterization. Journal of Geophysical Research, 103(c5):10391-10404. DOI: 10.1029/97JC03425

Hu, J.; Peng, P.; Jia, G.; Mai, B.; Zhang, G. (2006) Distribution and sources of organic carbon, nitrogen and their isotopes in sediments of the subtropical Pearl River estuary and adjacent shelf, Southern China. Marine Chemistry, 98(2-4):274-285. DOI: 10.1016/j. marchem.2005.03.008.

ICNB (Instituto da Conservação da Natureza e Biodiversidade) (2007) - Plano de Ordenamento da Reserva Natural do Sapal de Castro Marim e Vila Real de Santo António, $3^{a}$ Fase - Plano Final; relatório, 37p. http://portal.icnb.pt/ICNPortal/vPT2007 http://www. icnf.pt/portal/naturaclas/ordgest/poap/pornscmvrsa/ resource/ordenam/relat-ponder

IH (Instituto Hidrográfico) (2012) - Modelo batimétrico do Rio Guadiana. In: Download de dados geoespaciais relacionados com a Directiva INSPIRE [web page], Instituto Hidrográfico, Lisboa, Portugal. http://websig.hidrografico.pt/www/content/dados/ ModeloBatimetrico_RioGuadiana.rar

INAG - Instituto da Água (2001) - Plano de Bacia Hidrográfica do Rio Guadiana-Relatório Final. Partes I, II e III. 367p., Ministério do Ambiente e do Ordenamento do Território, Instituto da Água, Lisboa, Portugal. Available at http://www.apambiente.pt/_zdata/Politicas/ Agua/PlaneamentoeGestao/PBH2001/Guadiana_ RelatorioFinal.pdf

MARETEC (s.a.) - Definiçáo do Limite de Jusante dos Estuários Portugueses. In: MARETEC - Marine Environment \& Technology Center web page, Lisboa, Portugal. http://www.maretec.mohid.com/Estuarios/ Inicio/frame_page.htm

Jevrejeva, S.; Moore, J.C.; Grinsted, A.; Woodworth, P.L. (2008) - Recent global sea level acceleration started over 200 years ago? Geophysical Research Letters, 35(8):1-4. DOI: 10.1029/2008GL033611

Lewis, D.; McConchine, D. (1994a) - Analytical Sedimentology. 197p., Chapman and Hall, New York, NY, U.S.A. ISBN: 0442012160.
Lewis, D.; McConchine, D. (1994b) - Practical Sedimentology. 197p., Chapman and Hall, New York, NY, U.S.A. ISBN: 0442012179.

Lopes, J.; Neves, R.; Dias, J.; Martins, F. (2003) - Calibração de um sistema de modelação para o estuário do Guadiana. Thalassas, SI19(2b):139-140. Available at http://w3.ualg. pt/ jdias/JAD/papers/CI/03_4SM_155_JL.pdf

Machado, A.; Rocha, F.; Gomes, C.; Dias, J. (2007) Distribution and composition of suspended particulate matter in Guadiana estuary (southwestern Iberian Peninsula). Journal of Coastal Research (ISSN 0749.0208), SI50: 1040-1045. Australia. Available at http://www. griffith.edu.au/conference/ics2007/pdf/ICS189.pdf

Meyers, P.A. (1994) - Preservation of elemental and isotopic source identification of sedimentary organic matter. Chemical Geology (ISSN: 0009-2541), 114(3-4):289302. DOI: 10.1016/0009-2541(94)90059-0

Meyers, P.A. (1997) - Organic geochemical proxies of paleoceanographic, paleolimnologie and paleoclimatic processes. Organic Geochemistry, 27(5/6):213-250. DOI: 10.1016/S0146-6380(97)00049-1

Michel, D.; Wollast, R. (1978) - L'estuaire du Guadiana. In: Actions concertées en oceanographie. Rapport d'activite, 1978. Annexe $\mathrm{n}^{\circ}$ 7, Université Libre de Bruxelles, 99-149. Available at http://www.vliz.be/imisdocs/ publications/255391.pdf

Middelburg, J.; Nieuwenhuize, J.; Lubberts, R.K.; van de Plassche, O. (1997). Organic Carbon Isotopic Systematics of Coastal Marshes. Estuarine, Coastal and Shelf Science, 45(5):681-687. DOI: 10.1006/ecss.1997.0247

Miranda, P.; Coelho, F.; Tomé, A.; Valente, M.; Carvalho, A.; Pires, C.; Pires, H.; Pires, V.; Ramalho, C. (2002) 20th century Portuguese climate and climate scenarios. In: Santos, F.; Forbes, K.; Moita, R. (eds.), Climate change in Portugal. Scenarios, impacts and adaptation measures - SIAM project, pp.23-83, Gradiva, Lisboa. Available at http://siam.fc.ul.pt/siamI_pdf/SIAM $\% 20$ I\%20BOOK/2_ClimateScenarios.pdf

Morais, P. (2008) - Review on the major ecosystem impacts caused by damming and watershed development in an Iberian basin (SW-Europe): focus on the Guadiana estuary. Annales de Limnologie / International Journal of Limnology (ISSN: 0003-4088), 44(2):105-117.

Morais, P.; Chícharo, M.A.; Chícharo, L. (2009a) - Changes in a temperate estuary during the filling of the biggest Europeandam. Science of the TotalEnvironment, 407:22452259. DOI: $10.1016 /$ j.scitotenv.2008.11.037

Morais, P.; Teodósio, J.; Reis, J.; Chícharo, M.A.; Chícharo, L. (2009b) - The Asian clam Corbicula fluminea (Müller, 1774) in the Guadiana River Basin (southwestern Iberian Peninsula): Setting the record straight. Aquatic Invasions, 4(4):681-684. DOI: 10.3391/ai.2009.4.4.14

Morales, J.A. (1995) - Sedimentología del estuario del río Guadiana (S.O. España y Portugal). 323p., Universidad de Huelva, Huelna, España. ISBN: 978-8488751126.

Morales, J.A. (1997) - Evolution and facies architecture of the mesotidal Guadiana River delta (S. W. SpainPortugal). Marine Geology, 138(1-2):127-148. DOI: 10.1016/S0025-3227(97)00009-1 
Morales, J.A.; Delgado, I.; Gutierrez-Mas, J.M. (2006) Sedimentary characterization of bed types along the Guadiana estuary (SW Europe) before the construction of the Alqueva dam. Estuarine, Coastal and Shelf Science, 70(1-2):117-131. DOI: 10.1016/j.ecss.2006.05.049

Nieuwenhuize, J.; Maas, Y.; Middelburg, J. (1994) - Rapid Analysis of Organic Carbon and nitrogen in particulate materials. Marine Chemistry (ISSN: 0304-4203), 45(3):217-224. DOI: 10.1016/0304-4203(94)90005-1

Oliveira, A.; Fortunato, A.; Pinto, L. (2006) - Modeling the hydrodynamics and the fate of passive and active organisms in the Guadiana Estuary. Estuarine, Coastal and Shelf Science, 70(1-2):76-84. DOI: 10.1016/j. ecss.2006.05.033

Osborn, T.J. (2011) - Winter 2009/10 temperatures and a record-breaking North Atlantic Oscillation index. Weather, 66(1):19-21. DOI: 10.1002/wea.666

Osborn, Tim (2014) - North Atlantic Oscillation index data [web page]. In: Tim Osborn: Climate data, Climatic Research Unit (CRU), University of East Anglia, Norwich, U.K. Available at http://www.cru.uea.ac.uk/-timo/ datapages/naoi.htm

Phleger, F.B.; Bradshaw, J.S. (1966) - Sedimentary EnvironmentsinaMarineMarsh.Science, 154(3756):15511553. DOI: $10.1126 /$ science. 154.3756 .1551

RAMSAR (s.a.) - The List of Wetlands of International Importance. In: The Ramsar Sites Database [web page], RAMSAR Secretariat, Gland, Switzerland. http:// ramsar.wetlands.org/Database/Searchforsites/tabid/765/ Default.aspx

Rignot, E.; Velicogna, I.; van den Broeke, M.R.; Monaghan, A.; Lenaerts, J. (2011), Acceleration of the contribution of the Greenland and Antarctic ice sheets to sea level rise. Geophysical Research Letters, 38(5):1-5. DOI: 10.1029/2011GL046583.

Rocha, C.; Galvão, H.; Barbosa, A. (2002) - Role of transient silicon limitation in the development of cyanobacteria blooms in the Guadiana estuary, south-western Iberia. Marine Ecology Progress Series (ISSN: 0171-8630), 228:35-45. Available at http://www.int-res.com/articles/ meps2002/228/m228p035.pdf

Sampath, D.; Boski, T.; Martins, F.; Sousa, C.; Filhos, L.; Bezerra, F. (2011) - Forecasting and Hindcasting Longterm Morphological Evolution of Estuaries and Lagoons in Response to Sea Level Rise. Journal of Coastal Research (ISSN: 0749-0208), SI64:691-695. Available at http://www.ics2011. pl/artic/SP64_691-695_D.M.R.Sampath.pdf

Santos, F.; Forbes, K.; Moita, R. (2002) - Climate Change in Portugal. Scenarios, Impacts and Adaptation Measures - SIAM Project, 454 pp., Gradiva, Lisboa. Available at http://siam.fc.ul.pt/siamI_pdf/SIAM\%20I\%20BOOK/

Savenije, H. (2005) - Salinity and Tides in Alluvial Estuaries. 194p., Elsevier, Amsterdam, The Netherlands. ISBN: 978-0444521071.
Schuerch, M.; Rapaglia, J.; Liebetrau, V. (2012) - Salt Marsh Accretion and Storm Tide Variation: an Example from a Barrier Island in the North Sea. Estuaries and Coasts, 35(2):486-500. DOI: 10.1007/s12237-011-9461-z.

Sen Gupta, B.K. (1999) - Foraminifera in marginal marine environments. In: B.K. Sen Gupta (ed.), Modern Foraminifera, pp.141-160, Kluwer Academic Publishers, London, UK. ISBN: 0412824302.

Simonson, W. (2007) - Vegetation mapping of the Guadiana estuary. In: Simonson, W. (ed.), A Rocha Portugal Observatory Report for 2005-2006, pp.65-68, Associação A Rocha, Portimão, Portugal. Available at http://www. arocha.org/pt-en/7396-DSY/version/default/part/ AttachmentData/data/A\%20Rocha\%20Portugal\%20 2005-2006\%20report.pdf

SNIRH (1995-2014) - Sistema Nacional de Informação de Recursos Hidricos [web page], http://snirh.pt.

Sornin, J.M. (1983) - Influence de la biodeposition rhéologiques des vases. Journal de Recherche Oceanographique (ISSN: 0397-5347), 8(4):115-123, Institut Océanographique Paris, France.

Suguio, K. (2003) - Geologia Sedimentar. 400p., Editora Blucher, São Paulo, Brasil. ISBN: 978-8521203179.

Wolanski, E.; Chícharo, L.; Chícharo, M.A.; Morais, P. (2006) - An ecohydrology model of the Guadiana Estuary (South Portugal). Estuarine, Coastal and Shelf Science, 70(1-2):132-143. DOI: 10.1016/j.ecss.2006.05.029.

Wolanski, E. (2007) - Estuarine Ecohydrology. 157p., Elsevier, ISBN: 978-0444530660.

Vargas, C.; Oliveira, F.; Oliveira. A.; Charneca, N. (2008) Vulnerability Analysis of an Estuarine Beach to Inundation: Application to Alfeite Spit (Tagus Estuary). Revista de Gestão Costeira Integrada / Journal of Integrated Coastal Zone Management, 8(1): 25-43. DOI: $10.5894 /$ rgci26

Velicogna, I. (2009) - Increasing rates of ice mass loss from the Greenland and Antartic ice sheets revealed by GRACE. Geophysical Research Letters, 36(19):1-4. DOI: 10.1029/2009GL040222

Viles, H.; Spencer, T. (1995) - Coastal Problems: Geomorphology, Ecology and Society at the Coast. 350p., Edward Arnold, London. ISBN-13: 978-0340531976.

Zhou, J.; Wu, Y.; Zhang, J.; Kang, Q.; Liu, Z. (2006) Carbon and nitrogen composition and stable isotope as potential indicators of source and fate of organic matter in the salt marsh of the Changjiang Estuary, China. Chemosphere, 65(2):310-317. DOI: 10.1016/j. chemosphere.2006.02.026.

Zhou, J.; Wu, Y.; Kang, Q.; Zhang, J. (2007) - Spatial variations of carbon, nitrogen, phosphorous and sulfur in the salt marsh sediments of the Yangtze Estuary in China. Estuarine, Coastal and ShelfScience, 71(1-2):47-59. DOI: 10.1016/j.ecss.2006.08.012. 